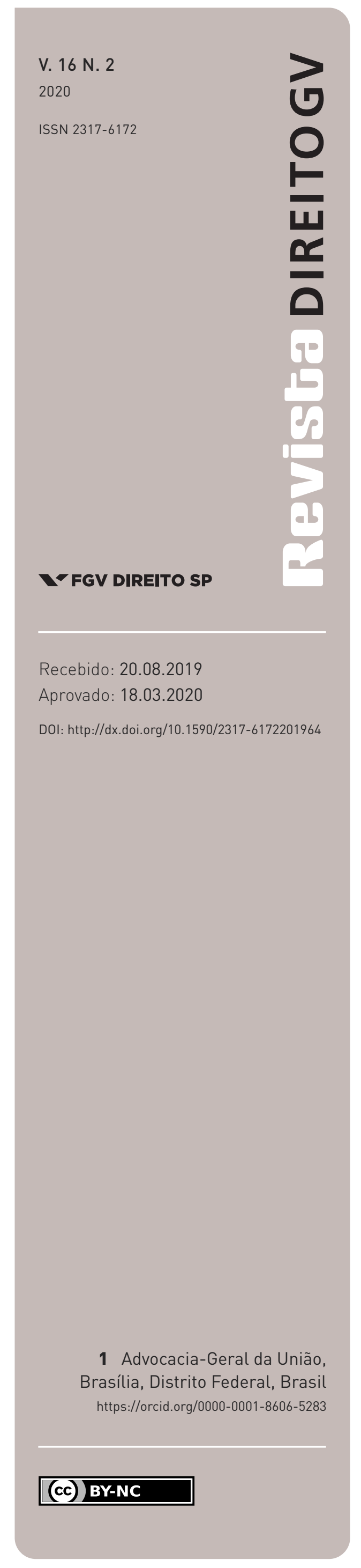

\section{O STF como árbitro da federação: uma análise empírica dos conflitos federativos em sede de ACO}

\author{
BRAZILIAN SUPREME COURT AS ARBITER OF THE FEDERATION: AN EMPIRICAL \\ ANALYSIS OF THE DIRECT FEDERATIVE CONFLICTS AT THE HEAD OFFICE OF PRIMARY \\ COMPETENCE OF THE SUPREME COURT (ACO) \\ Andrea de Quadros Dantas ${ }^{1}$
}

\section{Resumo}

0 presente artigo analisa a jurisprudência federalista do Supremo Tribunal Federal (STF), enquanto Tribunal da Federação, em complemento aos estudos já existentes, restritos ao controle concentrado de constitucionalidade. Parte-se da pesquisa empírica de todas as ações cíveis originárias (ACOs) ajuizadas entre 05/10/1988 e 31/12/2019, totalizando 2.948 ações, para delimitar o conceito de conflito federativo construído pela Corte e como são solucionados os litígios diretos entre União e Estados. Tal estudo descreve a evolução jurisprudencial, identificando as partes e os temas que são potencialmente capazes de instaurar o denominado conflito federativo, comparando-a com os dados estatísticos coletados. Ao reduzir a análise dos dados tão somente às ações instauradas entre a União e os Estados, identificou-se que o conflito federativo reconhecido pelo STF é essencialmente um litígio fiscal, no qual se discute a redistribuição de recursos da União para os Estados. Por fim, ao constatar a elevada taxa de êxito dos Estados, foi possível demonstrar uma descentralização do federalismo provocada pela atuação do STF. Tal conclusão desafia o entendimento consolidado na doutrina federalista brasileira, o qual afirma haver uma tendência centralista na jurisprudência do STF, e introduz novas complexidades a serem analisadas a respeito do impacto da atuação do STF sobre o federalismo.

\section{Palavras-chave}

Federalismo; Supremo Tribunal Federal; ação cível originária; estudo empírico; conflito federativo; finanças públicas.

\section{Abstract}

This paper analyzes the federalist jurisprudence built by the Brazilian Supreme Court (STF), acting as the Federation Court, in order to complement the existing studies, which are restricted to the concentrated control of constitutionality. The study begins with the empirical research of the civil actions based on the primary competence of the Supreme Court (ACO) filed between 05/10/1988 and 31/12/2019, which resulted in 2.948 actions, in order to unravel the concept of federative conflict built by the Court and to figure out how it solves the disputes between the central and the states governments. This study describes the jurisprudential evolution of the Federation Court, identifying the parties and themes that are potentially capable of establishing the so-called federative conflict, and compares it with the collected data. Moreover, by reducing the data study to the disputes between the Union and the States, it was identified that the federative conflict, thus recognized by the STF, is essentially a fiscal dispute, which discusses the redistribution of resources from the center to the states governments. Finally, by noting that States are generally the winners of such conflicts, it was possible to visualize a decentralization movement on Brazilian federalism as a result of the Supreme Court's jurisprudence. This conclusion not only challenges the majority understanding of the doctrine, restricted to the concentrated control of constitutionality, which affirms that there is a centralist tendency in the jurisprudence of the Court, but also 
introduces new complexities to be analyzed on the subject of the impact of STF's decisions on Brazilian federalism.

\section{Keywords}

Federalism; Brazilian Supreme Court; primary competence; empirical analysis; federative conflict; public finances.

\section{INTRODUÇÃO}

A definição de uma Corte Constitucional como guardiã do sistema federativo e árbitra dos conflitos que venham a surgir entre os entes federados encontra paralelo em diversos outros sistemas jurídicos. ${ }^{1}$

Entretanto, a análise da atuação do Supremo Tribunal Federal (STF), enquanto árbitro do sistema federativo brasileiro, deve observar uma característica peculiar da Corte brasileira, qual seja, suas atribuições extrapolam o âmbito estritamente constitucional. De fato, a Carta de 1988, além de reconhecer a clássica atribuição do STF como guardião da Constituição, lhe deferiu inúmeras outras competências originárias, ampliando, assim, o espectro de atuação dessa Corte sobre os potenciais litígios institucionais e sociais.

No que se refere ao conflito federativo, tal confronto pode surgir no STF essencialmente de duas formas distintas: no controle concentrado de constitucionalidade, quando se discute a distribuição de competências legislativas; e nos conflitos diretos entre União e Estados. Nesse ponto, é interessante esclarecer que praticamente todos os estudos sobre o impacto da jurisprudência do STF sobre o federalismo brasileiro restringem-se à análise das decisões em sede de controle concentrado de constitucionalidade. ${ }^{2}$

1 Tal ideia remonta aos clássicos Artigos Federalistas, nos quais Hamilton esclarecia que somente uma Corte nacional poderia ter a competência para uniformizar a interpretação de leis nacionais, sendo também de competência dessa Corte a função de impedir que os Estados viessem a usurpar as competências da União, o que seria concretizado mediante a declaração de nulidade de tais leis estaduais (HAMILTON et al., 1787/1788, n. 80). É importante ressaltar que, como o federalismo norte-americano formou-se pela união de Estados confederados, os Artigos Federalistas possuíam argumentos favoráveis à centralização do poder. Posteriormente, tal teoria foi aprofundada por diversos doutrinadores, que objetivam analisar os impactos da jurisprudência da Corte Constitucional sobre os respectivos sistemas federalistas. Nesse sentido: Aroney e Kincaid (2016); Bednar et al. (2001); Bednar (2009); Bzdera (1993); Popelier (2016).

2 Nesse sentido: Anacleto (2008); Anselmo (2006); Araújo (2008); Barbosa (2014); Benvindo e Costa (2016); Camargo (2009); Camargo (2014); Canello (2016); Condeixa (2007); Guimarães (2013); Horbach (2013); 
Merece referência, enquanto exceção a referido padrão de pesquisa, os estudos desenvolvidos por Arlota e Garoupa (2014) e Alorta (2015), os quais englobam outras espécies processuais, a partir de uma pesquisa jurisprudencial com o termo "conflito e poderes e União e Estado e constituição e 1988” no site do STF. ${ }^{3}$ De outro lado, embora o estudo da Fundação Getulio Vargas (FGV) (FALCÃO et al., 2014) trate da questão federalista, o enfoque recai sobre o acesso de cada um dos Estados à Suprema Corte, em especial em sede recursal, não tendo sido apresentados dados sobre as ações cíveis originárias (ACOs). Sendo assim, o estudo desenvolvido pela FGV não analisa os conflitos federativos instaurados diretamente no STF, nem como a Corte decide tais litígios.

Assim, a despeito de diversos estudos e artigos dedicados a analisar a jurisprudência federalista e os fundamentos das decisões do STF em sede de controle concentrado de constitucionalidade, a atuação dessa Corte enquanto Tribunal da Federação, ou seja, enquanto órgão judicial responsável por solucionar os conflitos federativos, ainda não foi objeto de uma pesquisa extensiva e detalhada.

Diante da impossibilidade de se estudar todas as espécies processuais que podem ser utilizadas para o acionamento do conflito federativo, o estudo volta-se para a investigação dos dados obtidos na pesquisa acerca das ACOs, com o intuito de delimitar o conflito federativo nessa espécie processual, preenchendo parcialmente o vácuo doutrinário acerca da jurisprudência do STF enquanto Tribunal da Federação. A completa ausência do estudo do conflito federativo sob tal enfoque confere um caráter original à presente pesquisa.

Nesse contexto, após esclarecer a metodologia de coleta de dados, consistente na análise quantitativa e qualitativa de um total de 2.948 ACOs ajuizadas entre 05/10/1988 e $31 / 12 / 2019$, o presente artigo descreve a evolução jurisprudencial do conceito de conflito federativo construído pelo STF, explorando inicialmente a relevância das partes processuais para a definição de tal conceito e comparando os achados jurisprudenciais com os dados levantados. A segunda parte do artigo restringe a análise dos dados tão somente às ações nas quais não há um litígio direto entre União e Estados, o que resultou na construção de uma jurisprudência defensiva do STF e na formulação de um conceito negativo de conflito federativo.

Leoncy (2011); Lima (2010); Maués (2005); Mello (2011); Oliveira (2009); Paixão (2007); Pereira (2010); Ranieri (2008); Riga (2007); e Vasques (2007).

3 Nesse sentido: "Our hypothesis is tested on a panel of data recording 119 decisions of the STF concerning disputes between the union and the states between 1988 and 2010 and collected by the authors. Our research encompasses all the relevant decisions (as explained below) made after the proclamation of the 1988 Constitution up to December 31, 2010. [...] Our dataset also encompasses different types of actions, such as: conflicts of competence ('CC'), civil actions based on the primary competence of the STF ('ACO'), actions based on the disobedience of a fundamental constitutional principle ('ADPF'), federal interventions ('IF'), reclamations ('RCL'), writs of mandado de segurança ('MS')" (ARLOTA e GAROUPA, 2014, p. 147 e 149; ARLOTA, 2015, p. 266). 
A terceira parte do artigo volta-se, então, para o estudo do núcleo essencial do conflito federativo, qual seja, o confronto direto entre União e Estados. O tratamento dos dados demonstrará que o conflito federativo reconhecido pelo STF é essencialmente um litígio fiscal, focado na redistribuição de recursos entre União e Estados. Ademais, a elevada taxa de êxito dos Estados, junto com a temática redistributiva, resultou na afirmação de que o STF possui uma atuação descentralizadora, em contraposição ao anterior consenso doutrinário que afirmava uma tendência centralista da Corte.

Por fim, a relevância da publicação dos dados reflete-se não apenas na originalidade e na exaustividade do levantamento realizado, como também na possibilidade de que tal estudo possa ser utilizado pelos demais pesquisadores para testar diversas hipóteses acerca da atuação do STF enquanto árbitro do federalismo brasileiro.

\section{Metodologia de Coleta de dados}

Inicialmente, é interessante esclarecer o motivo pelo qual foi selecionada a espécie processual denominada ação cível originária (ACO) como objeto de estudo sobre o conflito federativo, considerando que tal litígio também poderia emergir de outras competências originárias, como mandado de segurança $(\mathrm{MS})^{\mathbf{4}}$ ou intervenção federal (IF), ${ }^{\mathbf{5}}$ além da espécie processual mais estudada, a ação direta de inconstitucionalidade (ADI).

Diante da impossibilidade de se realizar uma investigação exaustiva de todas as espécies processuais potencialmente capazes de levar os conflitos federativos diretos entre União e Estados a julgamento perante o STF, tornava-se imprescindível um recorte do escopo da pesquisa. Entretanto, tal fragmentação deveria ser realizada de modo que o objeto a ser analisado ainda pudesse refletir de maneira factual tanto o conflito federativo judicial como o entendimento do STF sobre o referido litígio.

Para que fosse possível realizar tal delimitação, foram utilizadas duas informações essenciais. A primeira delas reporta-se ao recente estudo abrangendo todas as decisões colegiadas do STF que tratavam de conflito federativo, desenvolvido por Arlota e Garoupa (2014). Nesse estudo, observou-se a prevalência de ACOs como locus primordial para a resolução de litígios entre União e Estados ${ }^{6}$ seguida de ações sobre intervenção federal e de ações

4 Exemplificativamente, a discussão sobre as condições de refinanciamento das dívidas dos Estados, em face da interpretação da LC 151/2015, foi travada em sede de mandado de segurança.

5 Sobre a relevância da intervenção federal sobre o conflito federativo, vide: Mazzei et al. (2014) e Lewandowski (2018).

6 Nesse sentido: "In fact, Adins are only the third most frequent form of action in our dataset (only $15 \%$ of the total number of cases considered). The most frequent action in our dataset is the ACO (26\% 
diretas de inconstitucionalidade, a indicar a adequação da escolha da ACO como objeto de pesquisa jurisprudencial exaustiva. Ademais, a eleição dessa espécie processual também deriva da própria experiência profissional da autora deste estudo, que atua há mais de 14 anos como Advogada da União perante o STF. Tal rotina profissional lhe permitiu observar a prevalência das ACOs como espécie processual eleita para resolver o conflito federativo entre União e Estados.

Estabelecida a espécie processual adequada para o objeto do estudo do conflito federativo direto entre União e Estado, restava delimitar o período temporal sobre o qual recairia a pesquisa. Uma vez que a Constituição de 1988 reinaugurou o sistema federalista no Brasil, o marco inicial de coleta de dados foi exatamente a promulgação dessa Carta Constitucional, ou seja, 5 de outubro de 1988. Considerando o dinamismo e o constante ajuizamento de novas ACOs, definiu-se como marco final da amostra a data de 31 de dezembro de 2019.

Em resumo, a presente pesquisa fundamentou-se sobre a coleta das informações referentes a todas as ACOs ajuizadas entre 5 de outubro de 1988 e 31 de dezembro de 2019, o que resultou em uma amostra total de 2.948 ACOs.

Acerca da coleta e da classificação dos dados, algumas questões metodológicas merecem ser devidamente esclarecidas. Inicialmente, é importante destacar que o STF não possui um banco de dados específico de ACOs, de modo que foi necessária a efetiva coleta dos dados, mediante a pesquisa manual e numérica de todas as ações no site do STF, ajuizadas no período citado, apontando o ano de ajuizamento, as partes envolvidas (autor e réu), o assunto em debate, a existência e data da decisão liminar, e a existência de decisões terminativas (de mérito ou não) ou indicativas da pendência de julgamento pelo STF. A pesquisa não se limita, assim, ao tratamento de um banco de dados já existente, sendo a própria construção do banco de dados pela coleta manual das informações disponíveis no site do STF parte relevante dessa pesquisa.

Quanto à classificação das partes, a indicação do termo União ou a denominação de qualquer Estado da federação como autor ou réu indica, simplesmente, a presença do Poder Executivo federal (União) ou do Poder Executivo estadual. Não se ignora que os termos União e Estado englobam não apenas o Poder Executivo de cada uma dessas esferas, mas também os

of cases considered), which are lawsuits initiated at the STF rather than appealed. This is the case because, as mentioned previously, the STF is the solely competent court to rule on direct federal conflicts among members of the union (although technically there are different understandings when it concerns to municipalities). The second most frequent action included in our dataset is the IF, also reflecting original jurisdiction of the STF (21\% of cases considered). Finally, extraordinary appeals ("RE") represent $9 \%$ of our dataset. Other actions (including MS, ADPF, RCL, MI 1) account for 29\% of the dataset in dispersed ways" (ARLOTA e GAROUPA, 2014, p. 149, grifo nosso). 
poderes Legislativo e Judiciário, e os respectivos ministérios públicos e tribunais de contas. Entretanto, quando da coleta de dados, duas principais questões foram observadas que resultaram no recorte conceitual aqui apresentado.

O primeiro fator relaciona-se com o padrão de autuação utilizado pelo STF para rotular as partes do processo. Observou-se que a Corte emprega a nomenclatura União e Estados para se referir exclusivamente ao Poder Executivo dos respectivos entes federados, de modo que os demais poderes aparecem discriminados de maneira específica, como Assembleia Legislativa, Conselho Nacional de Justiça, Tribunal de Justiça, Ministério Público, etc.

Ademais, as estatísticas demonstram que as causas envolvendo órgãos dos poderes Legislativo ou Judiciário não eram suficientes para atrair a competência do STF como Tribunal da Federação. Nesse contexto, a restrição dos termos União e Estado, além de refletir uma opção metodológica de autuação do próprio STF, também visa conferir uma maior precisão acerca do conceito jurisprudencial sobre o conflito federativo.

As divisões temáticas fundamentaram-se nas clássicas repartições doutrinárias, de modo que, por exemplo, questões atinentes a licitação, concessão, servidor público estariam inseridas em direito administrativo. Entretanto, no que se refere especificamente à questão fiscal, o tema foi dividido em dois grandes grupos: (1) redistribuição ou acesso a recursos; e (2) Cadastro Único de Convênio (Cauc). O primeiro tema engloba toda discussão que vise o repasse, o aumento do valor a ser repassado ou o acesso dos Estados a determinado crédito ou benefício fiscal, que seja obstado pela União. Exemplificativamente, é possível citar os seguintes debates: o Fundo de Participação dos Estados (FPE), o Fundo de Desenvolvimento Nacional de Ensino (Fundef), o cálculo da Receita Líquida Real (RLR), as condições para o acesso a operações de crédito, o refinanciamento das dívidas dos Estados, entre outras formas de transferência ou acesso a recursos.

De outro lado, em função do elevado número de ações nas quais se discute o denominado Cauc, que visa concretizar as sanções previstas nos artigos 25 e 40 da Lei da Responsabilidade Fiscal (LRF), tal tema foi compartimentado de maneira individual, apesar de estar inserido na temática ampla de redistribuição ou acesso a recursos.

\section{CONCEITO JURISPRUDENCIAL NEGATIVO DE CONFLITO FEDERATIVO}

Considerando a amplitude de competências deferidas constitucionalmente ao STF, em atenção ao previsto em seu artigo 102, inciso I, da Constituição Federal, o conflito federativo pode exsurgir no STF por duas vias diversas: em sede de controle de constitucionalidade abstrato (nos termos das alíneas “a”, "b” e “p”, do citado dispositivo), quando se questiona essencialmente os limites da competência legislativa dos Estados em confronto com a exclusividade conferida à União em diversos temas; ou quando o conflito emerge em sua forma concreta, nos litígios de índole subjetiva travados entre a União e os Estados, nos termos da alínea "f" do artigo constitucional. 
Nesse contexto, a alínea "f” do inciso I, artigo 102 da Constituição Federal é responsável pela transformação do STF no denominado Tribunal da Federação, ocasião em que o STF não funciona mais adstrito à matéria constitucional, aproximando-se de uma instância ordinária.

Conforme já esclarecido, a despeito da multiplicidade de formas de acionamento do STF para a resolução do conflito federativo, a presente pesquisa tem por objeto o estudo empírico das ações cíveis originárias (ACOs).

Nesse contexto, o primeiro passo no tratamento dos dados coletados foi identificar, dentre todas as ACOs pesquisadas, quais delas foram ajuizadas em função de um potencial conflito federativo, ou seja, pela incidência da competência prevista na citada alínea " $\mathrm{f}$ ". Tal delimitação apontou para uma prevalência de ACOs ajuizadas perante o STF com fundamento na alínea "f" do inciso II, artigo 102 da CF/88, consoante ao que se observa no Gráfico 1.

GrÁFico 1 - DistribuiçÃo de ACOS POR FUndAMENTO LEGAl (AlínEAS do ART. 102 DA CF)

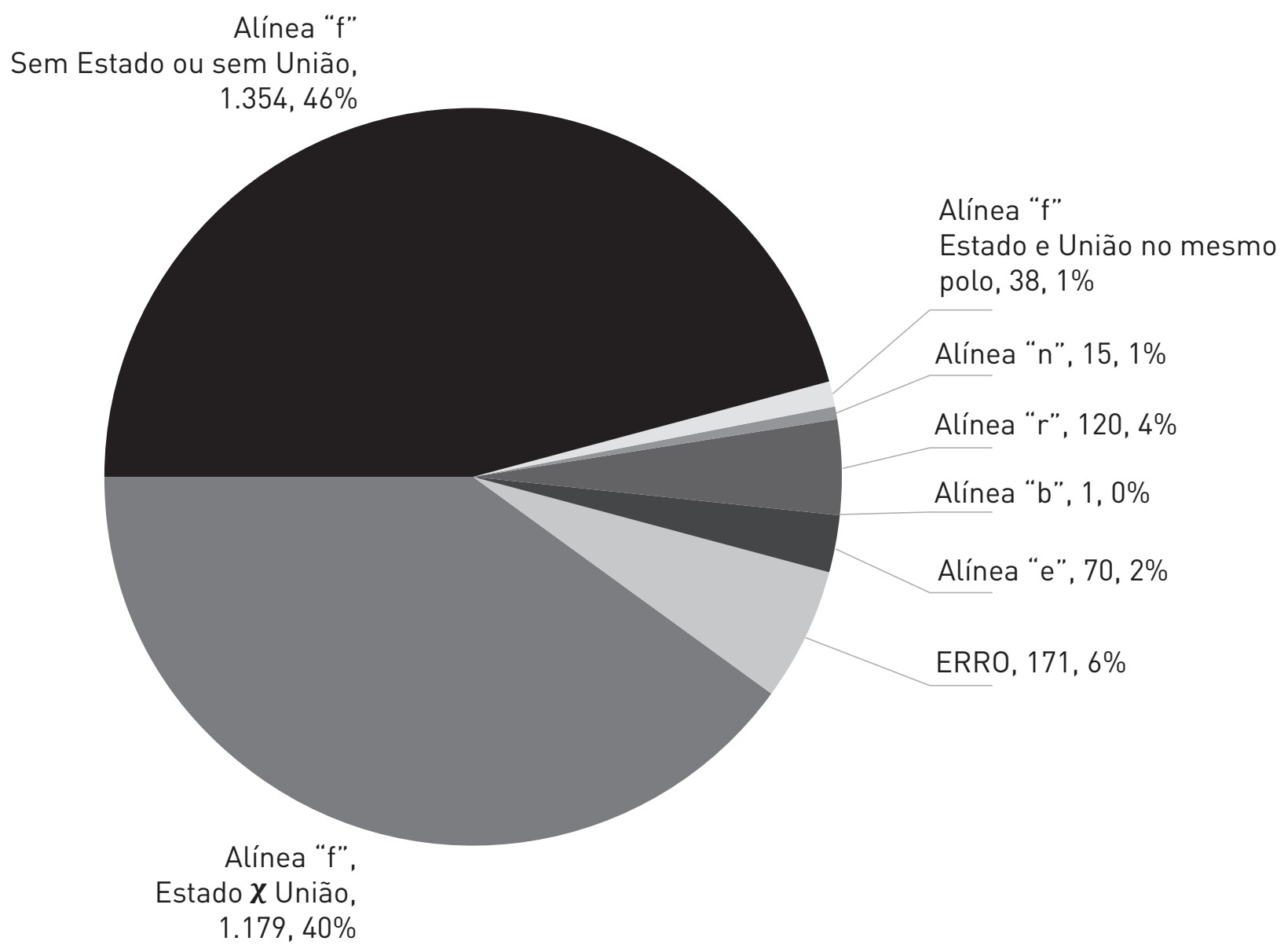

Fonte: Dados coletados do site do STF e tratados pela autora.

Assim, no que se refere às ações ajuizadas com fundamentos nas demais alíneas do artigo 102, inciso II, da CF, essas serão desconsideradas no espectro da pesquisa, por tratarem 
de questões alheias ao objeto do presente estudo. Os erros de autuação, que respondem por aproximadamente $6 \%$ (seis por cento) da amostra, também serão descartados do universo a ser analisado. ${ }^{7}$

No caso, foram localizadas 2.571 ações ajuizadas com fundamento na alínea 'f' do inciso II, artigo 102 da CF/88, o que corresponde a aproximadamente $87 \%$ do total de ACOs ajuizadas entre a promulgação da Constituição Federal e 31 de dezembro de 2019. Ademais, considerando que o foco da análise reside no conflito direto entre União e Estados, optou-se por realizar um novo recorte no tratamento de dados, a fim de se alinhar aos objetivos da pesquisa.

Para tanto, a amostra de 2.571 ACOs foi repartida em dois grandes grupos: aquele no qual há um conflito direto entre União e Estados, estando tais entes em polos opostos (1.179 ACOs); e aquele em que a União, o Estado ou ambos os entes federados não aparecem como partes no processo (1.354 ACOs). Esse segundo grupo será objeto dos tópicos 2.1 e 2.2, enquanto o estudo do litígio direto entre União e Estados será desenvolvido nos tópicos 3.1 e 3.2 deste artigo. Há, ainda, um grupo residual no qual a União e o Estado figuram no mesmo polo do processo ( $38 \mathrm{ACOs}$ ), o qual, por não indicar a presença de conflito federativo, não foi objeto de estudo específico. Esses três grandes grupos podem ser visualizados no Gráfico 1.

Ressalte-se, no ponto, que, apesar de o artigo constitucional eleger de modo idêntico os entes da administração direta e indireta como partes do potencial conflito federativo, a jurisprudência do STF mostra uma clara tendência de prevalência do reconhecimento de sua competência quando o litígio se desenvolve entre União e Estados. Exatamente por tal motivo, optou-se por delimitar o conceito jurisprudencial de conflito federativo tendo as partes como principal parâmetro. Para tanto, a princípio serão definidos quais conflitos federativos emergem sem a presença da União e dos Estados em polos opostos e, posteriormente, quais os contornos dos conflitos resultantes do litígio direto entre Estados e União.

Partindo daquela amostra das ACOs ajuizadas com fundamento na alínea "f”, mas na qual não há conflito direto entre União e Estados, somando 1.354 ACOs, observou-se a prevalência tanto da administração indireta como dos ministérios públicos como as principais partes litigantes, consoante ao exposto no Gráfico 2.

7 Foram considerados erros de autuação tanto as ACOs que não tinham qualquer processo autuado sob aquele número como aquelas que foram automaticamente reautuadas sob modalidade processual diversa. Foram localizadas 171 ACOs que correspondem a esses dois casos. 


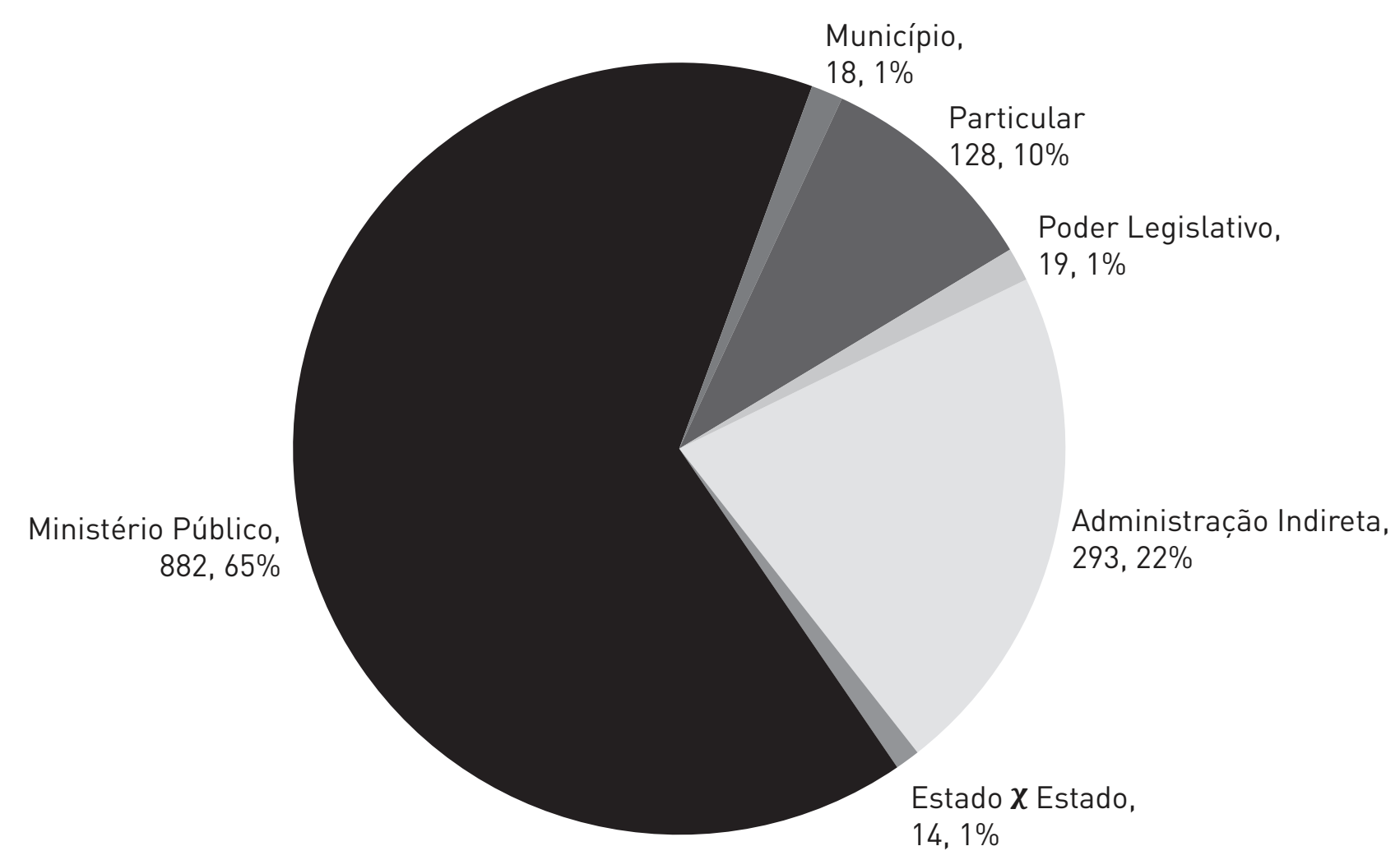

Fonte: Dados coletados do site do STF e tratados pela autora.

Por isso, o presente tópico partirá desses litígios para tentar identificar um conceito negativo de conflito federativo, descrevendo o histórico jurisprudencial do STF a partir das reduções conceituais estabelecidas pela Corte, em especial o afastamento dos órgãos da administração indireta e do Ministério Público como partes aptas a gerar um conflito federativo, e comparando tais achados jurisprudenciais com os dados levantados na pesquisa.

\section{I Primeira ReduÇÃo CONCeitual: AdministraÇÃo indireta}

Estabelecidas tais premissas, torna-se importante delimitar o alcance da competência do STF como Tribunal da Federação, no que se refere à presença da administração indireta como apta a confirmar o julgamento de mérito pelo STF. A análise meramente jurisprudencial do STF indica uma drástica redução do alcance literal da norma constitucional, para afirmar que sua competência somente se justifica diante de uma lide que efetivamente ponha em risco o pacto federativo, inserindo a temática do processo como elemento também definidor do conflito federativo. Entretanto, tal estudo não permitia a identificação de qual seria, então, esse conflito federativo capaz de acionar a competência do STF, mesmo quando em confronto entes da administração indireta.

A coleta e o tratamento dos dados, no ponto, permitiu não apenas a comprovação do achado jurisprudencial acerca da redução conceitual, como também a identificação do conflito 
federativo assim detectado pelo STF. O presente item parte, então, do estudo dos acórdãos paradigmáticos que formataram o entendimento do STF, para depois analisar como tal restrição conceitual se reflete nos dados coletados.

A interpretação restritiva surgiu ainda na vigência da Emenda Constitucional n. 1, de 17 de outubro de 1969, responsável pela inserção das entidades da administração indireta no dispositivo constitucional que estabelecia a competência ao STF, de modo semelhante à atual disciplina constitucional.

Essa restrição incidiu, primeiramente, nas entidades da administração indireta, quando o STF apenas reconheceu sua competência quando os entes em conflito estivessem localizados em Estados diferentes. ${ }^{\mathbf{8}} \mathrm{Na}$ oportunidade, restou afirmado que o conflito instaurado entre uma autarquia federal com representação estadual e o Estado-membro não configurava potencial ruptura do equilíbrio federativo apta a ensejar a competência originária do STF. Referido entendimento permaneceu consolidado na jurisprudência da Corte Suprema, mesmo após o advento da Constituição de 1988. Em questão de ordem suscitada na ACO n. 396, confirmou-se a necessidade de intervenção da União para que o conflito fosse classificado como federativo e, portanto, apto a atrair a competência do STF. ${ }^{9}$

Posteriormente, já sob a vigência da Constituição Federal de 1988, produziu-se uma "audaciosa redução do alcance literal da alínea questionada de sua competência original”, 10 para

8 Consoante ao que se observa do seguinte trecho do voto proferido pelo Ministro Xavier de Albuquerque: "Interpretando o acréscimo que ao dispositivo constitucional anterior fez a Emenda n. 1/69, relativamente aos órgãos da Administração indireta da União e dos Estados que naquele não figuravam, o Supremo Tribunal terminou por entender que sua competência só se caracterizava quando a causa envolvesse entes localizados em unidades federadas diferentes [...] Está a ideia perfeitamente explicitada na emenda do acórdão proferido na ACOr 192 (DJ 3/9/71): 'Ação Cível Originária. A Competência originária do Supremo Tribunal Federal só se caracteriza quando as pessoas jurídicas de direito público interno em litígio se localizam em unidades federadas diferentes. Art. 119, letra d, da Constituição Federal. Não conhecimento" (ACO 202). Nesse mesmo sentido: ACO n. 168, 173 e 175.

9 Nesse sentido: “Competência. Art. 102, i, 'f’, da Constituição Federal de 1988. Ação cível entre sociedades de economia mista da administração indireta federal e estadual. Justiça comum. Foro de eleição. Tratando-se de ação ordinária de cobrança, movida por sociedade de economia mista, integrante da administração indireta federal (Furnas - Centrais Elétricas S/A), contra sociedade de economia mista da administração indireta estadual (Cia Energética de São Paulo - CESP), enquanto não houver intervenção da União, a qualquer título (súmula 517), compete o respectivo processo e julgamento a justiça estadual de $1^{\circ}$ Grau (do Rio de Janeiro, no caso, face ao foro de eleição) - e não, originariamente, ao Supremo Tribunal Federal, por não haver risco de conflito federativo. Precedentes. Questão de ordem resolvida nesse sentido, com remessa dos autos a justiça estadual de $1^{\circ}$ Grau" (STF, ACO 396-QO, Rel. Min. Sydney Sanches, Tribunal Pleno, Julgamento em 28/03/1990).

10 STF, ACO 417-QO, Relator Ministro Sepúlveda Pertence, Órgão Julgador: Tribunal Pleno, Julgamento em 08/11/1990, Publicação em 07/12/1990. 
se concluir que "a aplicabilidade da norma inscrita no art. 102, I, f, da Carta Política restringe-se, tão somente, àqueles litígios cuja potencialidade ofensiva revele-se apta a vulnerar os valores que informam o princípio fundamental que rege, em nosso ordenamento jurídico, o pacto da federação". ${ }^{11}$ Essa redução do alcance literal do dispositivo levou o STF a estabelecer uma distinção conceitual entre conflito entre entes federados e conflito federativo. ${ }^{12}$

Restava, ainda, delimitar quais seriam, objetivamente, os valores fundantes do pacto federativo, cuja desestabilização seria capaz de acionar a competência originária do STF. Nessa linha, com o intuito de esclarecer as causas potencialmente capazes de desequilibrar o pacto federativo, no julgamento da questão de ordem na ACO n. 359, o ministro relator Celso de Mello ressaltou que “a composição de litígios de valores ínfimos, sem qualquer projeção de caráter institucional sobre as relações políticas entre as unidades federadas, especialmente quando o conflito se estabelece com entidade privada que compõe a administração indireta"13 não revelaria conflito federativo apto a firmar a competência constitucional da Suprema Corte como Tribunal da Federação. ${ }^{14}$

11 Frase constante em inúmeros precedentes do STF. Exemplificativamente: STF, ACO-QO n. 359, Relator Ministro Celso de Mello, Tribunal Pleno, DJ de 11/03/04; STF, ACO 641 AgR, Relator Ministro Celso de Mello, Órgão Julgador: Tribunal Pleno, Julgamento em 24/04/2003, Publicação em 03/06/2005; STF, ACO 1.048-QO, Relator Ministro Celso de Mello, Órgão Julgador: Tribunal Pleno, Julgamento em 30/08/2007, Publicação em 31/10/2007.

12 [... 3. Diferença entre conflito entre entes federados e conflito federativo: enquanto no primeiro, pelo prisma subjetivo, observa-se a litigância judicial promovida pelos membros da Federação, no segundo, para além da participação desses na lide, a conflituosidade da causa importa em potencial desestabilização do próprio pacto federativo. Há, portanto, distinção de magnitude nas hipóteses aventadas, sendo que o legislador constitucional restringiu a atuação da Corte à última delas, nos moldes fixados no Texto Magno [...] (ACO 1295-AgR-segundo/SP, Pleno, Rel. Min. Dias Toffoli, j. 14/10/2010, DJe de 02/12/2010).

13 ACO 359-QO, Relator Ministro Celso de Mello, Tribunal Pleno, DJ de 11/03/04, p. 42.

14 O seguinte trecho da ementa revela o crescimento da importância da questão material para o afastamento do conflito federativo: "[...] O art. 102, I, f, da Constituição confere ao STF a posição eminente de Tribunal da Federação, atribuindo-lhe, nessa condição, o poder de dirimir as controvérsias que, irrompendo no seio do Estado Federal, oponham as unidades federadas umas às outras. A jurisprudência do Supremo Tribunal Federal, na definição do alcance dessa regra de competência originária da Corte, tem enfatizado o seu caráter de absoluta excepcionalidade, restringindo a sua incidência às hipóteses de litígios cuja potencialidade ofensiva revele-se apta a vulnerar os valores que informam o princípio fundamental que rege, em nosso ordenamento jurídico, o pacto da Federação. Ausente qualquer situação que introduza a instabilidade no equilíbrio federativo ou que ocasione a ruptura da harmonia que deve prevalecer nas relações entre as entidades integrantes do Estado Federal, deixa de incidir, ante a inocorrência dos seus pressupostos de atuação, a norma de competência prevista no art. 102, I, f, da Constituição. - Causas de conteúdo estritamente patrimonial, fundadas em títulos executivos extrajudiciais, sem qualquer substrato político, não justificam que se instaure a competência do Supremo Tribunal Federal prevista no art. 102, I, f, 
Surge, assim, o cerne da ideia de que as causas meramente patrimoniais não teriam o fundamento necessário para justificar a competência originária do STF, dada a ausência de potencialidade de quebra do pacto federativo. Embora a negativa de jurisdição da questão patrimonial tenha surgido sob o enfoque de composição de litígios de valores ínfimos, tal parâmetro concretizou-se na jurisprudência do STF, de modo a afastar qualquer causa cujo conteúdo fosse exclusivamente patrimonial, independentemente do montante financeiro em discussão.

Por fim, o desenvolvimento da jurisprudência do STF, a despeito do que foi previsto expressamente no texto constitucional, acabou por afirmar que o conflito estabelecido entre órgãos da administração indireta, estadual ou federal, ainda que em face dos Estados ou da União, não seria suficiente para configurar um real conflito federativo. ${ }^{15}$

Entretanto, quanto ao reconhecimento do conflito federativo entre órgãos da administração indireta, o tratamento dos dados apontou para uma relevante exceção, qual seja, a discussão sobre imunidade tributária recíproca, temática essa prevalente nos julgamentos de mérito proferidos pelo STF nesse litígio em particular.

Sobre o tema, a competência da Suprema Corte foi reconhecida na Questão de Ordem na ACO n. 765, ${ }^{16}$ em que se discutia se a Empresa Brasileira de Correios e Telégrafos (empresa

da Constituição, ainda que nelas figurem, como sujeitos da relação litigiosa, uma pessoa estatal e um ente dotado de paraestatalidade (STF, ACO 359-QO, Relator Ministro Celso de Mello, Órgão Julgador: Primeira Turma, Julgamento em 04/08/1993, DJ 11/03/1993).

15 Nesse sentido, é esclarecedor o seguinte trecho da decisão monocrática proferida pelo Ministro Luiz Fux: "A diretriz jurisprudencial prevalecente no Supremo Tribunal Federal, firmada a partir da exegese da regra inscrita no art. 102, I, 'f', da Constituição, resultou de sucessivas decisões que não têm reconhecido, na mera instauração de processos judiciais, a possibilidade de ocorrência de conflito federativo, notadamente quando se tratar de causas promovidas (a) por sociedade de economia mista federal contra entidade da administração indireta de Estado-membro [...], ou (b) por sociedade de economia mista federal contra Estado-membro da Federação [...], ou (c) por sociedade de economia mista, instituída pelo Distrito Federal, contra Estado-membro [...], ou (d) por Estado-membro contra sociedade de economia mista federal [...], ou (e) por autarquia federal contra Estado-membro [...], ou (f) por empresa pública federal contra o Distrito Federal [...], ou, ainda, (g) por Estado-membro contra autarquia federal [...], mesmo porque consoante tem sido sempre enfatizado - tais controvérsias não caracterizam, só por si, 'conflito de interesses capaz de pôr em risco a harmonia federativa' [...]” (STF, ACO 663, Relator Ministro Celso de Mello, Decisão monocrática proferida em 07/04/2003).

16 Ementa do acórdão da ACO 765-QO: "CONSTITUCIONAL. COMPETÊNCIA. SUPREMO TRIBUNAL FEDERAL. [...] 3. Impossibilidade de tributação de bens públicos federais por Estado-membro, em razão da garantia constitucional de imunidade recíproca. 4. O fato jurídico que deu ensejo à causa é a tributação de bem público federal. A imunidade recíproca, por sua vez, assenta-se basicamente no princípio da Federação. Configurado conflito federativo entre empresa pública que presta serviço público de competência da União e Estado-membro, é competente o Supremo Tribunal Federal para o julgamento da ação cível originária, nos termos do disposto no artigo 102, I, 'f', da Constituição. 5. Questão de ordem que se resolve 
pública) detinha imunidade quanto ao Imposto sobre Veículo Automotor. Na oportunidade, o Ministro Sepúlveda Pertence destacou que a imunidade tributária recíproca seria parte do núcleo essencial da federação, eis que referida imunidade fundamenta-se exatamente na existência do condomínio político como federação. Apesar de o precedente ter sido firmado pela maioria dos votos, vencidos os Ministros Marco Aurélio e Carlos Velloso, consolidou-se a competência originária da Suprema Corte para julgamento de litígios que envolvam a existência ou a extensão da imunidade tributária, tendo em vista a potencialidade de desequilíbrio do pacto federativo. ${ }^{17}$

A análise dos dados coletados permitiu confirmar o reflexo dessa jurisprudência sobre o julgamento das ações que tinham a administração indireta como parte. De fato, o Gráfico 4 demonstra claramente o alto percentual de julgamentos pela incompetência do STF quando há litígio entre administração indireta e Estados ou União. Em cerca de 53\% dos casos houve afastamento da competência do STF por ausência de conflito federativo. Ademais, do grupo de ACOs, em que está presente a administração indireta e na qual o STF reconheceu sua competência, por decisão de mérito ou cautelar, tem-se somente 53 ACOs, sendo 36 delas sobre imunidade tributária (vide Gráficos 3 e 4).

pelo reconhecimento da competência do Supremo Tribunal Federal para julgamento da ação" (STF, ACO n. 765 QO, Relator Ministro Marco Aurélio, Relator para o acórdão Ministro Eros Grau, Órgão Julgador: Tribunal Pleno, Julgamento em 01/06/2005).

17 Exemplificativamente, cite-se as seguintes decisões tomadas com base no que foi decidido na ACO 765-QO: ACO 965; ACO 803 AgR; AC 1.757; ACO 1.460. 


\section{GRÁfico 3 - DistribuiçÃo de ACOS POR TiPo DE JUlGaMENTO, TENDO A}

\section{ADMINISTRAÇÃO INDIRETA COMO PARTE(S)}

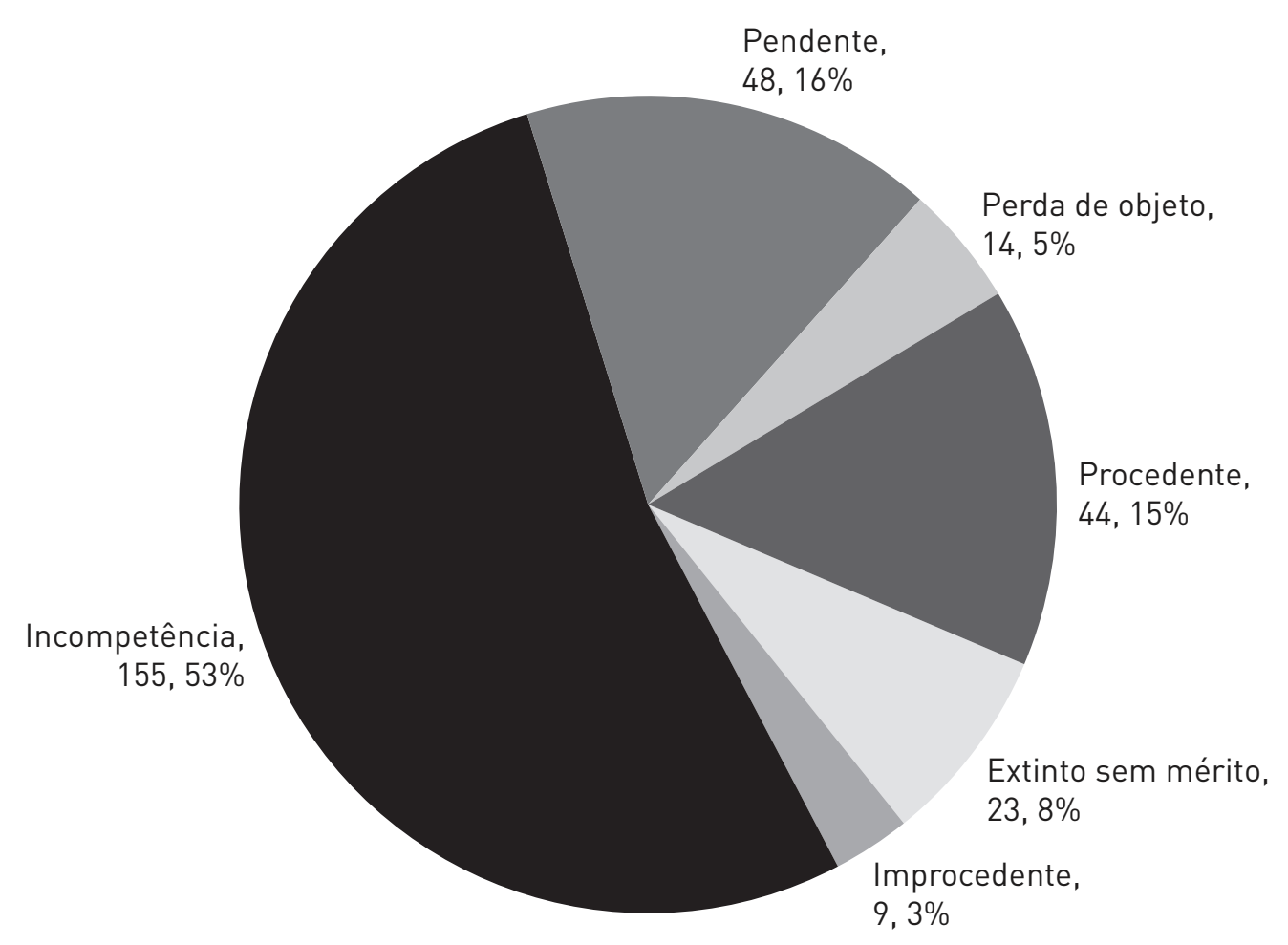

Fonte: Dados coletados do site do STF e tratados pela autora.

GRÁFICO 4 - DistribuiçÃo de ACOS POR TEMA, TENDO A ADMINISTRAÇÃo INDIRETA COMO PARTE(S)

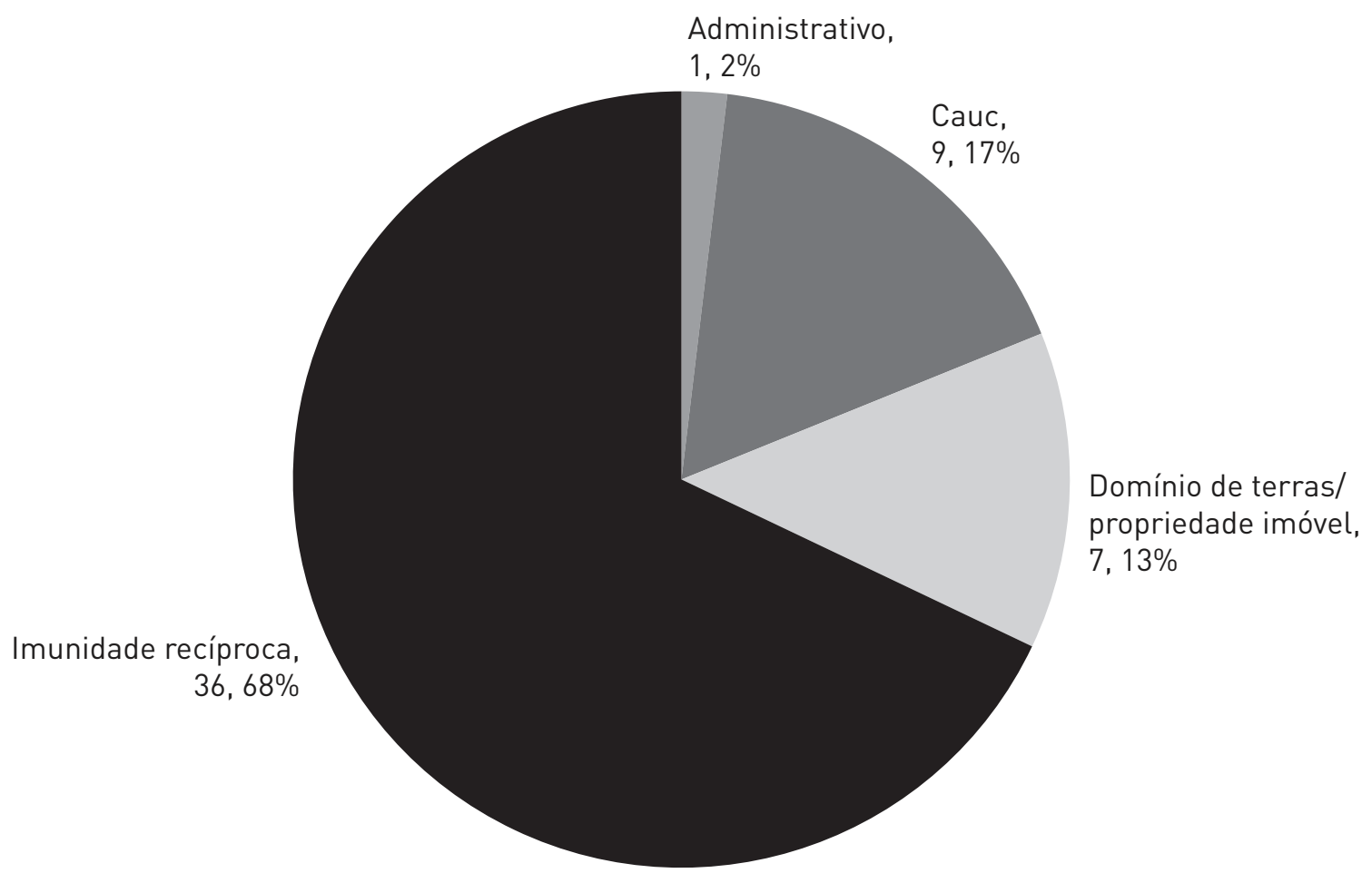

Fonte: Dados coletados do site do STF e tratados pela autora. 
Nesse contexto, é interessante observar que o tema de imunidade tributária recíproca ocupa a maioria absoluta (aproximadamente 68\%) dos conflitos federativos assim reconhecidos pelo STF entre órgãos da administração indireta e Estado ou União.

Embora a jurisprudência do STF pareça indicar que o conflito federativo poderia surgir do embate com entes da administração indireta, desde que observada a potencialidade de ruptura do pacto federativo, a análise minuciosa dos dados coletados indica que, atualmente, a presença da administração indireta somente é capaz de gerar potencial quebra do pacto federativo quando se discute ou a imunidade tributária recíproca de referidos entes, ou a transferência de verbas federais (Cauc).

Mas seria a administração indireta a única entidade excluída do conceito de conflito federativo?

\subsection{SEGUNDA RESTRIÇÃO CONCEITUAL: CONFLITO ENTRE MINISTÉRIOS PÚBLICOS ESTADUAIS E FEDERAL} Uma das surpresas surgidas da presente pesquisa foi a constatação do elevado número de ACOs ajuizadas sob o fundamento de potencial litígio federativo que discute os conflitos de atribuições entre os ministérios públicos estaduais e federal. De fato, aproximadamente 30\% de todas as ACOs ajuizadas no período em estudo tratam desse conflito de atribuições. ${ }^{18}$

É interessante observar que o STF analisava e resolvia os conflitos de atribuições, os quais se relacionavam essencialmente a qual ministério público (se federal ou estadual, ou de qual Estado) seria responsável por conduzir determinada investigação criminal ou demanda civil. De regra, a existência de conflito federativo capaz de acionar a competência originária da Suprema Corte não era devidamente discutida, e a simples prolação de uma decisão de mérito parecia indicar o reconhecimento de tal competência. ${ }^{19}$

O argumento essencial do reconhecimento da competência originária do STF fundamentava-se na ausência de deferimento constitucional de referida atribuição à Procuradoria-Geral da República, não havendo discussão concreta sobre como tal questão seria ou não capaz de provocar um desequilíbrio no pacto federativo. Percebe-se, nesse caso, que o conflito federativo era reconhecido por fundamento completamente diverso do conceito que havia sido construído pelo STF, no sentido da necessidade de comprovação de potencial ruptura do pacto federativo.

Entretanto, tal cenário começou a ser alterado em 21 de março de 2013, quando, no julgamento de um conflito de atribuições na ACO 1.394, o Ministro Teori Zavascki abriu

18 Foram localizadas 882 ACOs dentro da amostra de 2.948 que tratavam do conflito de atribuições entre esferas do Ministério Público.

19 A discussão dessa competência do STF surgiu inicialmente em sede de petição (PET), de modo que somente quando da alteração jurisprudencial tal questão pôde ser observada no julgamento das ACOs. 
divergência, suscitando a incompetência da Corte, por não estar qualificado o conflito federativo nos termos do artigo 102, inciso I, alínea “f”, da Constituição. ${ }^{20} \mathrm{O}$ tema, então, somente seria decidido pelo Plenário, por maioria de votos, vencido o Ministro Marco Aurélio, na sessão de 19 de maio de 2016, em julgamento conjunto com a ACO 924. ${ }^{21}$

Posteriormente, a jurisprudência do STF firmou-se "no sentido de que o conflito de atribuições entre membros do Ministério Público, ainda que envolva membro de Ministério Público estadual, não tem magnitude hábil a configurar o conflito federativo qualificado atrativo da competência originária desta Suprema Corte para o seu julgamento”. ${ }^{22}$

No caso, é interessante observar o reflexo da mudança de entendimento do STF sobre o número de ações ajuizadas sobre tal tema. Uma análise temporal dos dados demonstra uma queda brusca do ajuizamento dessa espécie de conflito de atribuições ainda em 2016 - eis que a jurisprudência da Corte se consolida no início desse ano (vide Gráfico 5).

20 Aqui se trata apenas da divergência que se estabeleceu a respeito da definição do órgão do Ministério Público que deve investigar determinado fato. Trata-se, portanto, de divergência estabelecida "interna corporis", em uma instituição que a Carta da República subordina aos princípios institucionais da unidade e da indivisibilidade $\left(\mathrm{CF}\right.$, art. 127 , parágrafo $\left.1^{\circ}\right)$. Divergência dessa natureza não se qualifica, portanto, como conflito federativo apto a atrair a incidência do art. 102, I, f, da Constituição, até porque, convém reafirmar, a solução supõe, necessariamente, um juízo de valor sobre o resultado da própria investigação a ser promovida e uma avaliação e tomada de posição sobre as providências judiciais ou extrajudiciais cabíveis, juízo esse inserido no âmbito do típico exercício das funções institucionais do Ministério Público, insuscetível de delegação ao Judiciário. Considerar essa divergência um conflito federativo significaria, por igual razão, atribuir essa mesma natureza à divergência, que certamente poderia ocorrer, entre órgãos das polícias judiciárias federais e estaduais para apuração desse mesmo fato. A exemplo do que ocorre no âmbito da polícia judiciária, cumpre ao próprio Ministério Público, e não ao Judiciário, identificar e afirmar, ou não, as atribuições investigativas de cada um de seus órgãos em face de um fato concreto.

21 Nessa oportunidade, o Ministro Teori Zavascki apresentou uma complementação do seu voto divergente, que se tornaria o voto condutor do acórdão, no qual assim desenvolveu o argumento pela incompetência do STF, dada a ausência de conflito federativo, verbis: "[...] São várias as razões que determinam se negue seguimento à presente demanda. Em primeiro lugar, porque não há, no caso, um conflito federativo com estatura minimamente razoável para inaugurar a competência do Supremo Tribunal Federal de que trata o art. 102, I, f, da Constituição. Realmente, conforme a jurisprudência assentada nesta Suprema Corte, não é qualquer conflito entre entes da Federação que autoriza e justifica a intervenção do STF, mas apenas aqueles conflitos federativos que (a) ultrapassam os limites subjetivos dos órgãos envolvidos e que (b) possuam potencialidade suficiente para afetar os demais entes e até mesmo o pacto federativo. [...]" (53/54).

22 Trecho da ementa da ACO 2.601. STF, ACO 2.601-AgR, Relatora Ministra Rosa Weber, Primeira Turma, Julgamento em 16/12/2016, Publicação em 13/03/2017. No mesmo sentido: STF, ACO 2.899-AgR, Relator Ministro Edson Fachin, Tribunal Pleno, Julgamento em 06/02/2017, Publicação em 01/08/2017. 


\section{GRÁFICO 5 - AJUIZAMENTO DE ACOS POR CONFLITO DE ATRIBUIÇÕES ENTRE MINISTÉRIOS PÚBLICOS POR ANO}

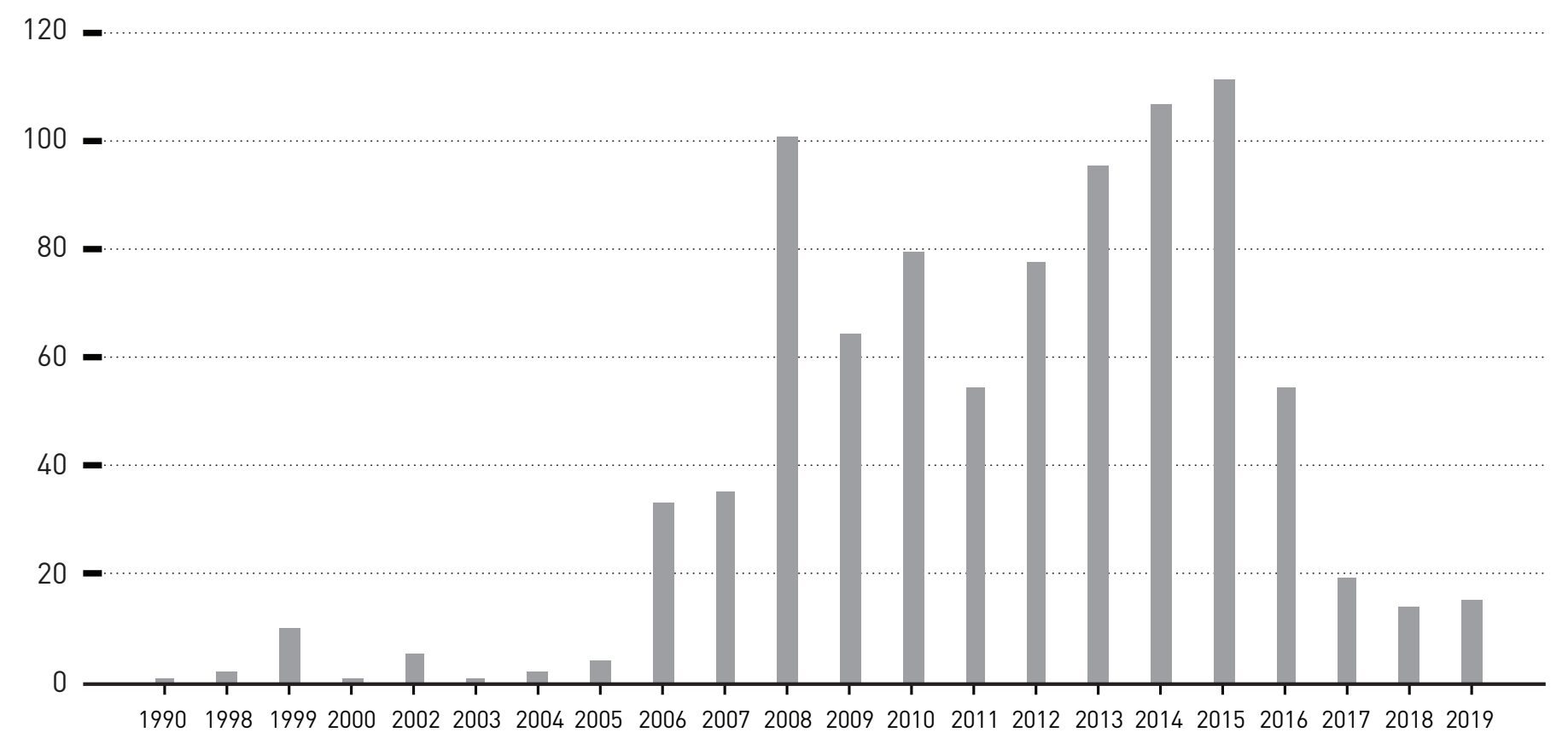

Fonte: Dados coletados do site do STF e tratados pela autora.

Tal dado parece indicar não apenas a alta efetividade das decisões do STF, como também uma possível correlação entre o grau de litigiosidade e a jurisprudência da Corte. Entretanto, a despeito da razoabilidade e da potencialidade dessa hipótese, a ausência de um conjunto mais amplo de dados, os quais incluam espécies processuais, temas e partes diversas das que foram aqui estudadas, não permite afirmar de maneira assertiva tal correlação.

Da análise da restrição conceitual relativa à presença de determinadas partes do litígio, foi possível perceber que, a despeito da instituição de um limitador temático para o reconhecimento do conflito federativo - a potencialidade de ruptura do pacto federal -, o fato é que o STF tende a afastar sua competência diante da presença de determinadas partes.

No tocante à discussão sobre domínio de terras ou nulidades de título de propriedade, a jurisprudência do STF mais recente tende a afastar sua competência para o julgamento de tais temas. ${ }^{23}$ Nesse contexto, é possível afirmar que, diante da ausência de um litígio direto entre União e Estados, atualmente somente as discussões sobre imunidade tributária recíproca e incidência das sanções previstas na LRF se inserem no conceito jurisprudencial de conflito federativo. 


\section{O CONFLITO FEDERATIVO ENTRE EsTAdos E UNiÃo}

Quando se observa somente o conflito entre a União e os Estados, a Constituição elegeu um único árbitro: o STF. No caso, da leitura do texto constitucional, a simples presença da União e de um ou mais Estados em polos opostos seria suficiente para configurar um conflito federativo. Entretanto, nem a análise jurisprudencial, nem o tratamento dos dados levantados, corroboram a amplitude dessa competência traçada pela Constituição.

Resta analisar, assim, o grupo de ACOs nas quais há o litígio direto entre União e Estados, com o intuito de melhor delimitar o conceito de conflito federativo e analisar a atuação do STF enquanto árbitro da federação brasileira. É interessante destacar, como já visto, que a restrição das partes envolvidas reduziu a amostra total de $2.571 \mathrm{ACOs}$, ajuizadas em função de um potencial conflito federativo, nos termos da alínea "f" do inciso II, artigo 102 da CF/88, para 1.179 ACOs que têm como partes antagônicas a União e um ou mais dos Estados ou o Distrito Federal.

\section{I CONFlito ENTRE OS ENTES FEDERAdos}

Como já destacado, a alínea constitucional que defere a competência de Tribunal da Federação ao STF estabelece que o conflito federativo emerge do litígio entre "a União e os Estados ou territórios ou entre uns e outros, inclusive os respectivos órgãos de administração indireta”. Entretanto, da análise da jurisprudência defensiva do STF, foi possível observar a quase completa exclusão dos órgãos da administração indireta dessa competência originária, com a ressalva acerca da discussão sobre imunidade tributária recíproca e residualmente sobre Cauc.

Nesse contexto, resta estudar um novo bloco de ações, consistentes nas causas em que ocorrem os conflitos diretos entre a União e os Estados, analisando novamente tanto os dados levantados como a construção jurisprudencial sobre a matéria. A princípio, considerando o texto literal da Constituição Federal e a presunção de que o litígio entre Estados e União seria suficiente para qualificar o conflito federativo, o STF reconhecia sua competência pela simples presença das citadas partes em polos opostos. Entretanto, dados e jurisprudência indicam que a evolução do entendimento do STF caminhou no sentido da restrição do conteúdo literal da Constituição.

Inicialmente, a Corte fixou-se na literalidade do texto constitucional, construindo um entendimento diverso de conflito federativo, quando em confronto dois entes federados, em relação àquele formado no litígio com órgãos da administração indireta. Ao decidir um caso no qual a União figurava como ré, por ter se tornado sucessora da Empresa Brasileira de Transportes Urbanos (EBTU), empresa pública em liquidação, ${ }^{24}$ o STF, considerando haver

24 Na oportunidade, a incompetência do STF foi suscitada em parecer do Ministério Público Federal (STF, ACO 447-QO, Relator Ministro Octavio Gallotti, Tribunal Pleno, Julgamento em 05/03/1993, Publicação em 14/05/1993, p. 34 dos autos). 
uma diferença essencial entre a presença de órgão da administração indireta e a da União, afirmou a existência de conflito federativo pela simples presença da União e do Estado em polos opostos. ${ }^{25}$

Um fundamento citado pelo Ministro Ayres Brito indicava a natureza política da União e dos Estados, em contraste com aquela meramente administrativa dos órgãos da administração indireta, como causa razoável para o discrímen até então apresentado pelo STF. Nessa linha de entendimento, a dimensão federativa do conflito entre União e Estados decorreria da natureza política dos entes envolvidos. ${ }^{26}$

Posteriormente, mesmo nos conflitos diretos entre União e Estados, surgiu a necessidade de se comprovar uma potencial ruptura do pacto federativo como fator determinante para a definição da competência do STF. A despeito da análise exaustiva das ACOs, não foi possível observar exatamente qual o precedente responsável pela mudança definitiva do posicionamento do STF, uma vez que, durante os anos de 2003 até 2010, a jurisprudência oscilava e era possível perceber decisões monocráticas reconhecendo a competência do STF pela simples presença dos entes políticos no litígio. ${ }^{27}$

Um dos primeiros precedentes sobre o tema refere-se à questão de ordem na ACO 379, quando a Corte, reconhecendo o caráter meramente patrimonial da disputa entre o Estado da Paraíba e a União, afastou a competência originária do STF, tendo por único fundamento a existência de precedentes da Corte. É interessante observar que os precedentes citados se referem a decisões proferidas em litígios em que estão presentes órgãos da administração indireta e até Estado estrangeiro, ${ }^{28}$ não havendo referência sequer a um precedente sobre o reconhecimento da competência do STF para as causas entre União e Estados.

Consoante a isso se observa no seguinte trecho do voto condutor do acórdão: "O temperamento instituído pelo Tribunal, em relação aos entes da administração indireta, segundo a natureza da causa, não encontra lugar, em meu entender, quando se passe a tratar de ação em que sejam formalmente partes, num polo, a União Federal e, no outro, algum Estado da Federação, ou o Distrito Federal. Nessa última hipótese, que é a dos autos (Autor o Distrito Federal e Ré a própria União), julgo inarredável o reconhecimento da competência originária do Supremo Tribunal Federal, nos termos do art. 102, I, f, da Constituição" (STF, ACO 447-QO, Relator Ministro Octavio Gallotti, Tribunal Pleno, Julgamento em 05/03/1993, Publicação em 14/05/1993, p. 35 dos autos). No mesmo sentido: ACO 449/DF, Relator Ministro Maurício Corrêa, Tribunal Pleno, DJ de 14/2/03; e ACO 427/DF, Relator Ministro Octavio Gallotti, Tribunal Pleno, DJ de 4/12/98, ACO 435, Relator Ministro Dias Toffoli.

26 STF, ACO 518-QO, Relator Ministro Joaquim Barbosa, Tribunal Pleno, Julgamento em 24/06/2004, publicação em 20/08/2004, trecho do voto do Ministro Ayres Britto, p. 20/21.

27 Nesse sentido: ACO 625, Relator Ministro Celso de Mello, decisão monocrática de 24/08/2009.

28 Foram citados os seguintes precedentes: ACO 509 (litígio entre dois órgãos da Administração Indireta - IGBE e Ceped, na qual se discute a competência do STF quando autarquia federal tem sede, filial ou escritório 
A priori, a mudança de entendimento acerca da competência do STF para resolver litígios entre União e Estados não poderia prescindir da reanálise do que foi decidido nas ACOs 447 e 449. Isso porque, naquela oportunidade, o STF expressamente havia afastado a possibilidade de adoção de uma interpretação restritiva do dispositivo constitucional, para afirmar sua competência diante da simples presença dos entes federados em polos opostos. Entretanto, apesar da ausência de uma maior fundamentação jurídica e da mudança de posicionamento não ter afastado os argumentos constantes nas ACOs 447 e 449, o julgamento da ACO 379 passou a ser citado como fundamento suficiente para o reconhecimento da incompetência do STF quando se reconhecia mero conflito patrimonial entre a União e um ou mais Estados da Federação. ${ }^{29}$

Novamente, a questão patrimonial teve reflexo fundamental no afastamento da competência do STF para o julgamento de causas instauradas entre a União e os Estados, destacando-se especialmente as questões relacionadas às execuções entre os entes federados, sejam essas fiscais ou extrajudiciais. De fato, de um total de 1.179 ACOs instauradas entre União e Estados, em 204 delas a competência do STF foi expressamente afastada. Desse universo de decisões pela incompetência, em aproximadamente $68 \%$ a Corte utilizou expressamente o fundamento patrimonial para negar a existência de conflito federativo ${ }^{30}$ (vide Gráfico 5).

O problema surge exatamente quando, embora não seja possível inferir uma discussão meramente patrimonial, o STF insiste em afirmar que aquele litígio em questão não seria capaz de abalar o equilíbrio federativo. Nesses casos, de regra, há mera citação no sentido de que o conflito posto em julgamento não possui "densidade suficiente para abalar o pacto federativo". 31

de representação ou de apoio no Estado-membro com a qual estabeleceu o litígio; ACO 543 (trata-se de execução de dívida ativa fiscal proposta pela União contra o Consulado Geral da República da Coreia em São Paulo, não havendo sequer conflito entre entes federados; ACO 477, litígio entre autarquia federal/ Incra e Estado-membro (TO), sobre propriedade de terras devolutas; e ACO 359, tratava de entes da administração indireta como visto no tópico precedente.

29 STF, ACO 518-QO, Relator Ministro Joaquim Barbosa, Órgão Julgador: Tribunal Pleno, Julgamento em 24/06/2004, Publicação em 20/08/2004.

30 Das 204 decisões pela incompetência, foram localizadas 139 decisões, nas quais havia expressamente o fundamento de se tratar de questão meramente material. De regra, nas decisões restantes, o STF se restringia a afirmar a ausência de conflito denso o suficiente para abalar o pacto federativo.

31 ACO 1.469, Relator Ministro Dias Toffoli, decisão monocrática proferida em 14/03/2014. Na oportunidade, o ministro afastou a competência da Corte, sob o seguinte fundamento: "De fato, a questão guarda relação com o ente federal apenas porque (i) o impacto da atuação danosa, supondo configurada, recai sobre bem constitucionalmente indicado como propriedade da União - o mar territorial (art. 20, VI, CF); e (ii) pela legitimidade jurídica que lhe foi concedida para realização da defesa do meio ambiente em âmbito 
Um caso paradigmático nesse sentido foi a decisão monocrática, cujo recurso de agravo ainda encontra-se pendente de julgamento colegiado, proferida pelo Ministro Edson Fachin, afastando a competência do STF para os julgamentos de ações em que se discutia a Transposição do Rio São Francisco. ${ }^{32} \mathrm{O}$ fundamento primordial para uma nova e drástica redução interpretativa do artigo 102, inciso II, alínea "f”" da Constituição Federal foi a necessidade de se conferir primazia ao papel do STF como Corte Constitucional. ${ }^{33}$

Seguindo esse parâmetro de relevância da função do STF como Corte Constitucional, a nova restrição interpretativa visa convergir a competência originária de resolução dos conflitos federativos à usurpação de competência legislativa, já abrangida pelo controle concentrado de constitucionalidade. Assim, apesar da indicação de se tratar de discussão essencialmente técnica como fundamento para afastar a competência do STF, o Ministro relator indica que a atuação do Suprema Corte enquanto Tribunal da Federação deveria estar restrita às questões que "fazem referência à usurpação das competências constitucionalmente atribuídas à União ou aos Estados, ou à afetação da autonomia dos entes federativos envolvidos no Projeto".

Após tal análise, pode-se delimitar alguns elementos aptos a descaracterizar determinado litígio como conflito federativo. O primeiro deles refere-se às causas meramente patrimoniais, independentemente do valor em discussão. Tal restrição afastou da competência do STF o julgamento de questões relacionadas a execuções entre os entes federados, bem como sobre as formas de compensação e cálculo tributários.

Quanto aos casos em que o STF afasta a competência para seu julgamento afirmando de maneira genérica a ausência de conflito federativo relevante, o tema que mais se destaca é

judicial, nos termos da Lei 7.347/1985. Trata-se, portanto, de litígio estritamente ambiental, desvestido de qualquer projeção de caráter institucional e sem possibilidade de afetar as relações políticas entre as unidades federadas, não possuindo densidade suficiente para abalar o pacto federativo, sendo, portanto, inapto para provocar a manifestação do STF na qualidade de Tribunal da Federação”.

32 O Ministro Edson Fachin proferiu decisão monocrática idêntica em todas as seguintes ações: ACO 787, ACO 820, ACO 857, ACO 870, ACO 872, ACO 873, ACO 876, ACO 886, ACO 996, ACO 1.003, ACO 1.052 e ACO 2.862 .

33 Nesse sentido, o seguinte trecho da decisão do ministro proferida na ACO 787: "Sob a luz de sua precípua função de Corte Constitucional, cujo principal escopo é evidenciado pela guarda da Constituição, é já passada a hora de questionar-se sobre quais motivações justificam a sua atuação para outros fins que não o de dar cumprimento à sua maior missão institucional, afastando-se quaisquer outras atribuições meramente revisionais de atos dos demais órgãos do Poder Judiciário ou da apreciação de causas que não revelem densidade suficiente para atribuir novos significados aos preceitos constitucionais. No caso dos autos, não encontro motivação jurídica que justifique a atuação desta Corte, com fundamento no art. 102, I, f, da Constituição Federal”. 
a discussão sobre domínio de terras ou nulidade de títulos de propriedade (vide Tabela 1). Outras restrições são mais fluidas, como o afastamento de questões unicamente ambientais e de políticas públicas nacionais, mas que parecem indicar uma tendência restritiva e majoritária da Corte. A Tabela 2 descreve os demais temas que resultaram no não reconhecimento do conflito federativo.

TABEla 1 - ACOS ENTRE UniÃo E ESTAdOS. DistribUiÇÃo POR TEMAS NOS JULGAMENTOS PELA INCOMPETÊNCIA DO STF. AUSÊNCIA DE CONFLITO FEDERATIVO

TEMA

QUANTIDADE

TRIBUTÁRIO

49

ADMINISTRATIVO

46

DOMÍNIO DE TERRAS/IMÓVEL

41

CAUC

21

COBRANÇA - UNIÃO SUCESSORA EBTU

15

REDISTRIBUIC̣ÃO/ACESSO DE RECURSO

15

AMBIENTAL

8

COMPETÊNCIA LEGISLATIVA

4

CAUC SUBSIDIÁRIO

2

REFINANCIAMENTO DE DÍVIDA

2

SIAFI (ANTES DO CAUC)

1

TOTAL

204

Fonte: Dados coletados do site do STF e tratados pela autora. 
TABela 2 - ACOS ENTRE União E Estados. DistribuiçÃo POR TEMAS NOS CASOS EM QUE O STF RECONHECEU SUA COMPETÊNCIA PARA JULGAMENTO DO PROCESSO. PRESENÇA DE CONFLITO FEDERATIVO

TEMA

QUANTIDADE

CAUC

441

REDISTRIBUIC̣ÃO/ACESSO DE RECURSO

81

TRIBUTÁRIO

30

ADMINISTRATIVO

12

DOMÍNIO DE TERRAS/IMÓVEL

15

REFINANCIAMENTO DE DÍVIDA

15

SIAFI (ANTES DO CAUC)

8

COBRANC̣A - UNIÃO SUCESSORA EBTU

7

COMPETÊNCIA LEGISLATIVA

2

DESMEMBRAMENTO DO ESTADO

2

AMBIENTAL

1

CAUC SUBSIDIÁRIO

1

TOTAL

615

Fonte: Dados coletados do site do STF e tratados pela autora.

Se a jurisprudência negativa não parece ter sido suficiente para delimitar tal conceito, talvez a peça faltante de tal quebra-cabeça esteja nas ações em que o STF reconheceu sua competência como Tribunal da Federação.

\subsection{O CONFLITO FEDERATIVO ENTRE UNIÃO E ESTADOS}

Com o intuito de melhor delimitar o conceito jurisprudencial de conflito federativo, serão 
analisados e indexados todos os temas que foram capazes de atrair a competência do STF enquanto Tribunal da Federação.

Ressalte-se, inicialmente, que, como será possível observar a seguir, a oscilação do entendimento do STF resultou na presença de temas idênticos na amostra dos conflitos federativos e naquela em que houve afastamento expresso da competência da Corte.

Ademais, embora seja possível depreender da análise jurisprudencial do STF que o litígio entre União e Estados tenha que ser relevante o suficiente para pôr em risco o equilíbrio federativo, mesmo após a análise exaustiva das ACOs, não foi possível delimitar de maneira clara os contornos dessa potencialidade de abalo do pacto federativo. Nesse cenário, observa-se que a Corte mantém uma estratégia de delimitação de conceitos vagos (potencialidade ofensiva que se revele apta a vulnerar os valores que informam o princípio federativo) que lhe permite selecionar discricionariamente os casos que entender relevantes o suficiente para firmar a competência da Suprema Corte. ${ }^{34}$

Se a jurisprudência stricto sensu não é capaz de indicar os contornos específicos do conflito federativo, talvez a análise dos temas julgados possa trazer novas e importantes nuances para tal definição. Assim, no presente momento, serão estudados apenas os dados referentes às ACOs ajuizadas entre União e Estados que possuam decisão de mérito (monocrática ou colegiada), pela procedência ou improcedência da ação, ou decisão cautelar que reconheça a competência da Corte, mesmo estando pendente o julgamento de mérito.

Tal amostra representa um conjunto de 615 ACOs, ou seja, pouco mais de 50\% de todas as ACOs em que Estados e União litigam em polos opostos (1.179). O Gráfico 6 demonstra a divisão por tema das ACOs nas quais o STF reconheceu, de maneira implícita ou explícita, a presença do conflito federativo. 


\section{GRÁFico 6 - DistribuiçÃo de ACOS POR TIPO DE JULGAMENTO NOS CONFLITOS DIRETOS ENTRE UNIÃO E ESTADOS}

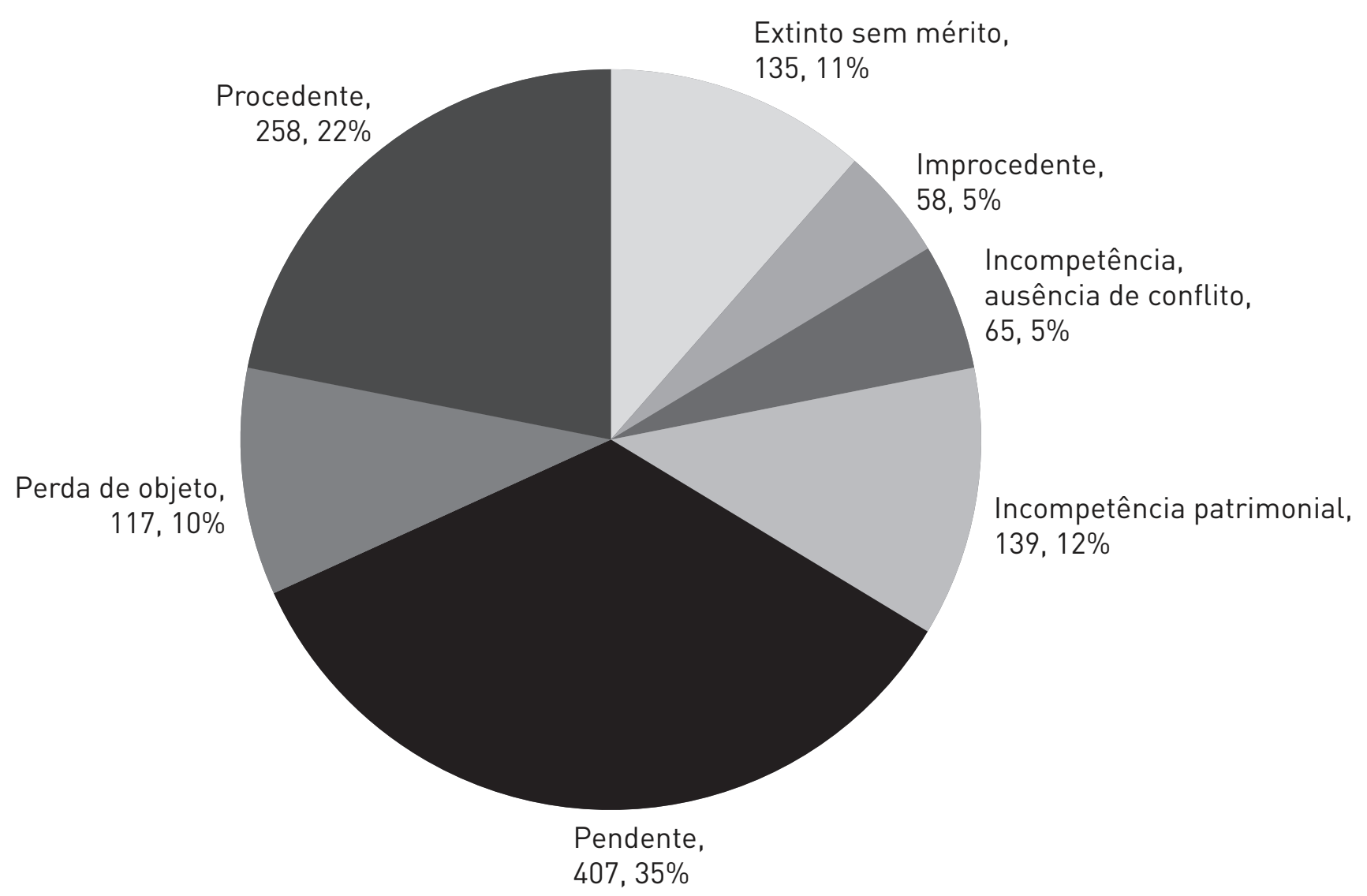

Fonte: Dados coletados do site do STF e tratados pela autora.

Analisando esse bloco jurisprudencial no qual o STF reconheceu a existência de conflito federativo (615 ACOs), observou-se que, em aproximadamente 73\% das ACOs, se discute a regularidade da inscrição dos Estados em cadastros de inadimplência do governo federal, em cumprimento ao disposto nos artigos 25 e 40 da LRF, ${ }^{35}$ e a discussão acerca do CAUC aparece como o conflito federativo mais recorrente no STF.

$\mathrm{O}$ segundo tema quantitativamente mais relevante reporta-se à denominada repartição ou acesso a recursos pelos Estados (13\%). Dentro de tal temática, inserem-se as discussões sobre o cálculo do percentual das parcelas destinadas aos Estados, a vinculação de tais recursos, o cumprimento de requisitos para acesso a operações de crédito, a desoneração de tributos por parte da União, a execução de contragarantia pela União e demais formas de repasse de verbas da União para os Estados. Exemplificativamente, tal tema envolve discussões acerca eram utilizadas para averiguar a incidência dos artigos da LRF antes da implementação do Cauc. 
do Fundo de Participação dos Estados, do cálculo das parcelas destinadas à educação (Fundef e Fundeb), da fórmula de cálculo da Receita Líquida Real, do percentual de royalties do petróleo e das perdas financeiras por desoneração de tributos redistribuídos aos Estados.

O terceiro tema que mais se repete nas decisões de mérito do STF está relacionado às questões tributárias (5\%), em especial à imunidade recíproca, à constitucionalidade e à compensação de tributos. Novamente, a jurisprudência do STF reafirma a relevância da repartição da competência tributária para a configuração e o equilíbrio do contrato federativo, em especial o princípio da imunidade tributária recíproca como pilar fundamental do federalismo brasileiro. A seguir, têm-se as discussões acerca dos contratos de refinanciamento das dívidas estaduais $(2,5 \%)$, as quais se reportam tanto às negociações ocorridas no final dos anos 1990 como àquelas que se concretizaram recentemente. Os demais temas estão listados no Gráfico 6.

Quando se estabelece uma temática federalista fiscal geral, a qual compreenderia todas as questões referentes ao recebimento e à utilização de recursos públicos, seria possível englobar os seguintes temas constantes da Tabela 2: Cauc (441); redistribuição/acesso a recursos (81); tributário (3); refinanciamento da dívida (15); e Siafi (8). Nesse cenário, a temática federalista fiscal somaria 548 ACOs, o que representa $89 \%$ dos conflitos federativos entre União e Estados, assim reconhecidos pelo STF.

Novamente, as peculiaridades envolvendo o critério patrimonial também devem ser minuciosamente observadas nos casos que envolvem os convênios e as transferências de recursos entre União e Estados. Isso porque, embora a jurisprudência do STF tenha afastado de sua competência a discussão dos termos da execução do convênio, manteve-se no rol de atribuições do Tribunal da Federação o julgamento da negativa da União em repassar verbas aos Estados em razão do descumprimento daquele dispositivo da LRF.

Dessa análise preliminar, é possível afirmar que o conflito federativo entre a União e os entes federados, que necessita da interveniência da Suprema Corte, está majoritariamente relacionado à descentralização de recursos da União, ou seja, o conflito federativo permanece essencialmente fundado na questão fiscal.

Estabelecido tal contorno temático, é interessante observar se as estatísticas acerca dos julgamentos sobre o conflito federativo em sede de ACOs poderiam indicar alguma tendência jurisprudencial do STF. Para tanto, deve ser realizada uma compartimentalização dessa amostra na qual o STF reconheceu o conflito federativo, restringindo-a aos processos em que houve julgamento de mérito pela Corte. Tal recorte resultou em uma amostra de 316 ACOs, as quais representam o conjunto de ações no qual o STF decidiu definitivamente o litígio entre União e Estados.

Uma primeira análise dos dados aponta que o conflito federativo é instigado, majoritariamente, pelos Estados, sendo esses os autores em 92\% da referida amostra, contra 8\% de casos em que a União figura como autora da ACO (vide Tabela 3). Ademais, a análise dos dados mostra que o Estado foi vencedor das demandas judiciais em aproximadamente $79 \%$ dos casos, 
enquanto foram proferidas decisões favoráveis à União em aproximadamente $21 \%$ dos julgamentos de mérito (vide Gráfico 7). ${ }^{36}$ TABEla 3 - ACOS ENTRE União E EsTAdos. DistribuiçÃo POR TIPO DE JULGAMENTO,
CONSIDERANDO O POLO PROCESSUAL DA UNIÃO E DOS ESTADOS

PARTE AUTORA

ESTADO AUTOR

PROCEDENTE

IMPROCEDENTE

MPROCEDENTE

UNIÃO AUTORA

PROCEDENTE

IMPROCEDENTE

(MPROCENTE

\section{PERCENTUAL}

$92,4 \%$

$76,6 \%$

$15,8 \%$

$7,6 \%$

$5,1 \%$

$2,5 \%$

8

Fonte: Dados coletados do site do STF e tratados pela autora.
16

QUANTIDADE DE ACOS

\section{2}

242

50

24 


\section{GrÁfico 7 - ACOs entre União e Estados.TAXA de ÊXito dos Estados E dA União NOS PROCESSOS EM QUE O STF RECONHECEU SUA COMPETÊNCIA PARA O JULGAMENTO}

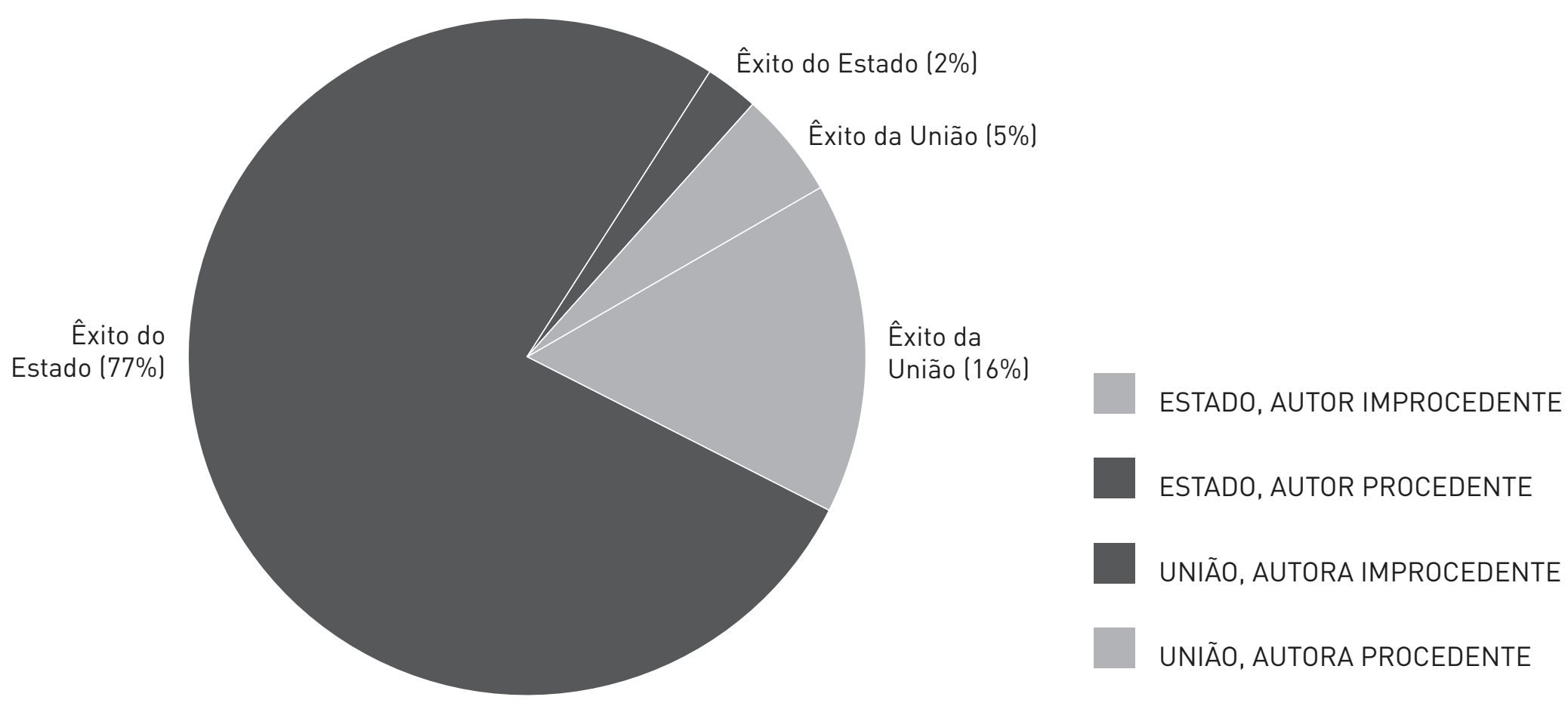

Fonte: Dados coletados do site do STF e tratados pela autora.

Da análise dos dados coletados, percebe-se que, em sede de ação cível originária, o conflito federativo é essencialmente um litígio acerca da redistribuição de recursos da União para os Estados, ou retenção de receitas pela União, o qual é decidido majoritariamente em favor dos Estados. Considerando essas duas premissas, pode-se afirmar que a jurisprudência da Corte, em sede de ACO, favorece a descentralização dos recursos da União para os Estados, reforçando o movimento centrífugo das verbas e descortinando uma tendência descentralizadora do STF.

Diante da análise temática e da taxa de êxito, ainda não é possível afirmar que o STF tenha um posicionamento que favoreça os Estados em detrimento da União. Entretanto, considerando que as ações de temática fiscal objetivam essencialmente um maior acesso a recursos, o qual havia sido negado pela União, é possível afirmar que tal jurisprudência promove uma maior descentralização de recursos do centro para os entes subnacionais.

De outro lado, para que seja possível suscitar um eventual favorecimento dos Estados na construção jurisprudencial da Corte, torna-se necessária uma análise dos fundamentos decisórios dos principais temas decididos pelo STF. A despeito da impossibilidade de se estudar todos os temas, alguns serão aqui expostos como indicativo de existência de um efetivo favorecimento dos Estados nos conflitos federativos.

Nessa linha, é interessante uma breve incursão no tema de maior relevância quantitativa na amostra pesquisada, qual seja, o Cadastro de Convênios da União, conhecido como Cauc. 
Em síntese, tal cadastro visa concretizar os mandamentos previstos nos artigos 25 e 40 da LRF, evitando que sejam repassadas transferências voluntárias ou seja concedida a garantia da União em operações de créditos aos Estados que estejam inadimplentes perante a União.

Se analisarmos somente as ações que tratam do Cauc, é possível observar novamente não apenas uma prevalência de êxito dos Estados nas decisões de mérito, como também um alto percentual (92\%) de cautelares decididas em favor dos Estados. ${ }^{37}$ No que se refere especificamente às decisões de deferimento de liminares, os dados demonstram que em cerca de $85 \%$ dos casos as liminares são concedidas em menos de 30 dias $^{\mathbf{3 8}}$ (vide Gráfico 8). Outro dado relevante sobre tal tema reporta-se à demora da Corte - pouco mais de 10 anos em proferir o primeiro acórdão de mérito, o que aponta para a existência de um extenso lapso temporal de alto percentual de deferimento de liminares, sem a análise aprofundada do tema em debate.

\section{GRÁFICO 8 - NÚMEROS DE LIMINARES DEFERIDAS $\chi$ DiAS ENTRE O AJUIZAMENTO DA AÇÃO E O DEFERIMENTO DA LIMINAR}

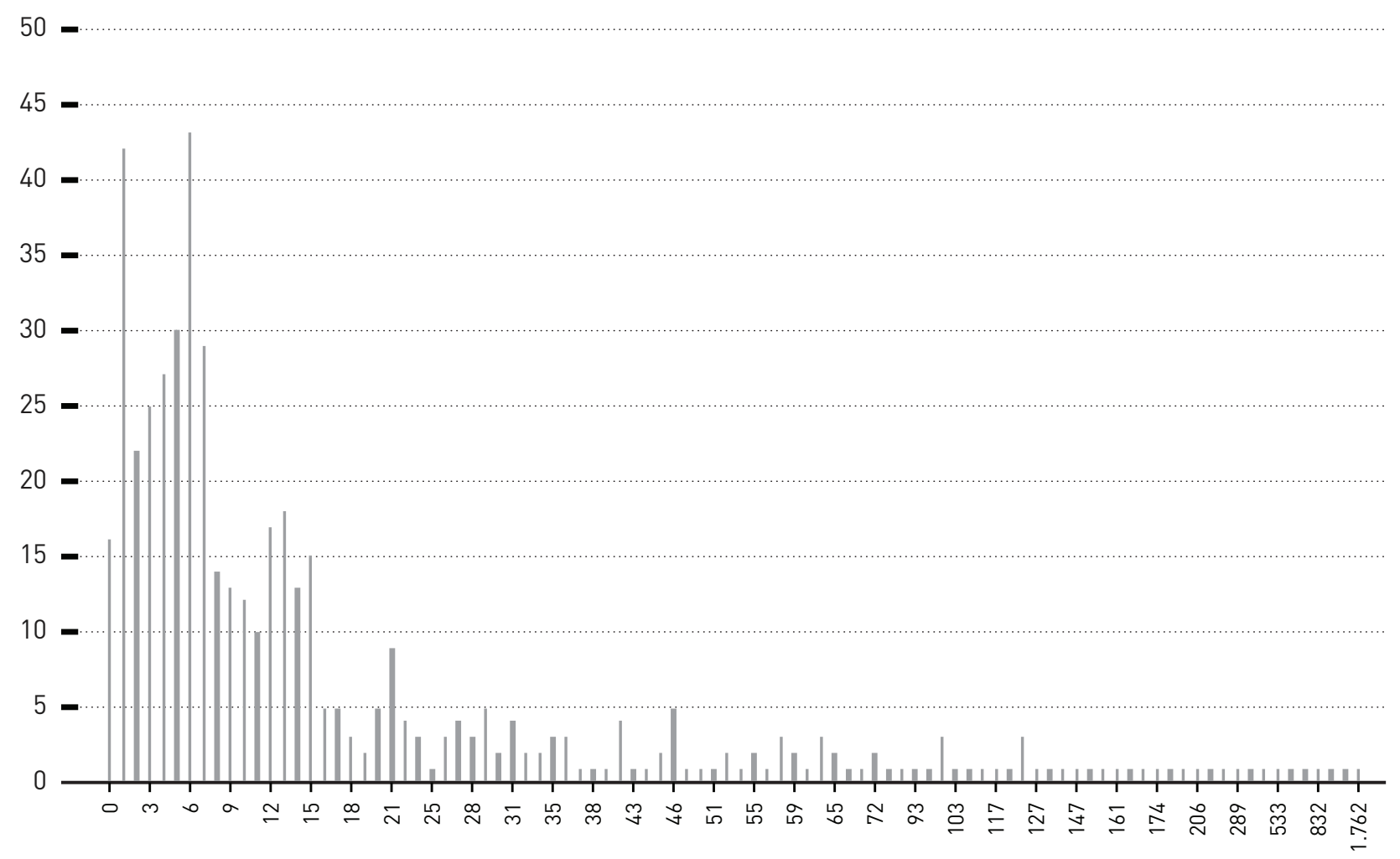

Fonte: Dados coletados do site do STF e tratados pela autora.

\section{$\bullet \bullet$}

37 Da análise dos dados coletados, foi possível observar que, das 532 decisões em que o STF apreciou o pedido de tutela antecipada, em 491 a Corte determinou que a União realizasse a transferência voluntária questionada ou conferisse o necessário aval para a operação de crédito requerida pelo Estado. Ressalte-se que o STF não analisou o pedido cautelar em 52 ações, e em 14 ACOs a liminar foi deferida na origem.

Das 491 decisões concessivas do pedido cautelar, 318 delas foram concedidas em menos de 10 dias e 98 , entre 11 e 30 dias. 
Dito em outras palavras, referidas decisões liminares permitem o acesso imediato dos Estados às transferências voluntárias ou ao aval para a concretização das operações de crédito, ainda que não cumpridos os requisitos exigidos na LRF. De outro lado, os fundamentos expostos tanto nas decisões cautelares como nas de mérito repisam uma suposta integral dependência dos Estados em relação aos recursos a serem repassados pela União, apontando para a construção de uma imagem de hipossuficiência dos Estados, a justificar uma intervenção em favor de tais entes.

Para se compreender todas as peculiaridades da formação da jurisprudência dessa temática específica pelo STF, seria necessário um novo estudo, no qual fosse possível analisar todo o histórico de aprovação da LRF, de construção do sistema de controle pela Secretaria do Tesouro (o Cauc), do acionamento do STF pelos Estados, dos argumentos expostos pela União e, por fim, da construção do entendimento pelo STF, aprofundamento esse que não é o objeto primordial do presente artigo.

Ainda sobre as decisões proferidas pelo STF e seu eventual favorecimento dos Estados, atualmente, dois relevantes temas fiscais ocupam a Suprema Corte, quais sejam, a execução de contragarantias contratuais pela União, a qual resultaria em retenção de recursos dos Estados, e a discussão sobre a necessidade de os Estados cumprirem todos os requisitos legais para se beneficiarem do regime de recuperação fiscal previsto nas LCs 156 e 159.

Em ambos os casos, a despeito da existência de normas contratuais ou legais que permitiam a contestada atuação da União, seja de retenção de verba, seja de negativa de adesão ao regime de recuperação fiscal, o STF também deferiu um alto percentual dos pedidos liminares, exonerando os Estados do pagamento das contragarantias contratuais e do cumprimento dos requisitos legais para a adesão ao regime de recuperação fiscal. ${ }^{39} \mathrm{O}$ fundamento primordial para a concessão das cautelares reporta-se ao denominado princípio da solidariedade federalista, reforçando a ideia da União como guardiã prioritária do equilíbrio fiscal da federação e da hipossuficiência dos Estados em garantir tal equilíbrio.

Embora a comprovação da hipótese de que a jurisprudência do STF favoreça os Estados em detrimento da União, revertendo responsabilidades contratuais e legais, dependa de um estudo mais aprofundado tanto dos dados quanto dos argumentos expostos pela Corte, os dados confirmam que o conflito federativo que se desenvolve no STF tem o Estado como o grande vencedor e, em função da prevalência da temática fiscal, promove a descentralização de recursos, ampliando o aspecto centrífugo da estrutura federalista brasileira.

Foram localizadas 15 ACOs que tratam da execução de contragarantia, e em todas elas o pedido liminar foi deferido. Quanto ao debate sobre a adesão dos Estados ao regime de recuperação fiscal, tem-se 18 ações, com cautelares deferidas em 10 delas. Ressalte-se que foram indeferidos somente 3 pedidos cautelares, e os demais não foram analisados. 


\section{CONSIDERAÇÕES FINAIS}

O STF talvez seja a instituição mais estudada pelos juristas brasileiros, permanecendo, entretanto, um gigantesco quebra-cabeça cujas peças teimam em não refletir espécie alguma de retrato institucional. A maior dificuldade em se decifrar tal enigma relaciona-se não apenas com a extensão - de competências e de quantidade de ações -, como também com a oscilação dos julgamentos da Suprema Corte, que nem sempre formam uma jurisprudência estável ou coerente.

No tocante ao impacto da jurisprudência do STF sobre a estrutura federalista, os estudos até então existentes, os quais se debruçavam sobre o controle concentrado de constitucionalidade, apontavam um caráter centralista da Suprema Corte, na medida em que suas decisões ampliavam o alcance interpretativo da competência legislativa concorrente ${ }^{40} \mathrm{e}$ privativa da União, e ainda restringiam o poder constituinte estadual, ao alargar o sentido da expressão "simetria constitucional". ${ }^{41}$

Como já ressaltado, a única exceção refere-se às pesquisas desenvolvidas por Arlota e Garoupa (2014) e Arlota (2015), nas quais foram analisadas todas as decisões que tratavam de federalismo desde a promulgação da Constituição de 1988 até 31 de dezembro de $2010 .{ }^{42}$ $\mathrm{Na}$ oportunidade, contrariando as pesquisas anteriormente apresentadas, os autores afirmaram que os dados coletados pareciam infirmar a tese segundo a qual a Suprema Corte brasileira é, em essência, centralista. No ponto, ressaltaram que a amplitude de competências do STF poderia ser a causa da jurisprudência oscilante observada na pesquisa, a demonstrar decisões favoráveis tanto para a União como para os Estados em percentuais muito próxi-

mos. ${ }^{43}$ É possível, contudo, que a ausência de uma conclusão mais precisa seja resultado da metodologia de tratamento dos dados realizados pelos autores.

40 Nesse sentido: Anselmo (2006); Mello (2011); Ranieri (2008); Vasques (2007).

41 Nesse sentido: Anselmo (2006); Araújo (2008); Condeixa (2007); Guimarães (2013); Horbach (2013); Leoncy (2011); Lima (2010); Maués (2005).

42 Nesse sentido: "Our hypothesis is tested on a panel of data recording 119 decisions of the STF concerning disputes between the union and the states between 1988 and 2010 and collected by the authors. Our research encompasses all the relevant decisions (as explained below) made after the proclamation of the 1988 Constitution up to December 31, 2010. [...] Our dataset also encompasses different types of actions, such as: conflicts of competence ('CC'), civil actions based on the primary competence of the STF ('ACO'), actions based on the disobedience of a fundamental constitutional principle ('ADPF'), federal interventions ('IF'), reclamations ('RCL'), writs of mandado de segurança ('MS')” (ARLOTA e GAROUPA, 2014, p. 147 e 149).

"Our dataset consists of 1,008 individual observations in reference to 119 decisions by the STF during the period from the proclamation of the Constitution of 1988 to December 31, 2010. The main statistics are: $54 \%$ of those individual votes were favorable to the state (548 votes) and $46 \%$ were favorable to the union (460 votes)" (ARLOTA e GAROUPA, 2014, p. 153). 
Isso porque, a despeito da originalidade e do avanço promovido por tal estudo, a análise dos dados foi apresentada de maneira global, sem a compartimentalização por espécie processual, o que impediu os autores de visualizarem um padrão (centrípeto ou centrífugo) na jurisprudência do STF. É exatamente essa falha que se pretende que seja suprida com a análise dos dados apresentados neste artigo.

De fato, a amplitude de competências do STF para a resolução do conflito federativo impõe uma análise também compartimentada, porém não isolada, da atuação do STF.

Retomando as conclusões decorrentes da análise estatística das ACOs, observou-se que o conflito federativo em ACO é essencialmente um litígio fiscal travado entre União e Estados, e a jurisprudência do STF favorece os Estados, promovendo a descentralização de verbas, o que se traduziria em uma tendência descentralizadora do STF. No caso, as taxas de êxito dos Estados junto com as temáticas decididas pelo STF apontaram claramente no sentido de uma maior descentralização de recursos da União para os Estados.

Ao efetuar tal compartimentalização, é possível perceber duas tendências distintas na jurisprudência federalista do STF. Assim, sem refutar os estudos anteriores sobre o caráter centralista do STF em sede de controle concentrado de constitucionalidade, pode-se afirmar que a jurisprudência do STF centraliza o federalismo brasileiro, seja reduzindo a autonomia constituinte dos Estados, seja alargando as competências legislativas da União. Por outro lado, ao decidir os conflitos diretos entre União e Estados, em sede de ACO, o STF promove um movimento de descentralização de recursos, revelando uma tendência centrífuga na jurisprudência da Corte.

Em outras palavras, conjugando os estudos já realizados sobre o tema com as conclusões retiradas da análise dos dados da presente pesquisa, é possível afirmar que a jurisprudência do STF promove um movimento dual sobre o federalismo brasileiro, na medida em que centraliza as competências legislativas nas decisões em sede de controle concentrado de constitucionalidade, mas promove a descentralização de recursos quando instado a decidir o litígio direto entre União e Estados em sede de ACO.

Essa observação contribui para problematizar a anterior visão centralista da jurisprudência do STF, com o intuito de melhor compreender a atuação da Corte sobre a estrutura federalista brasileira.

Nesse contexto, alguns questionamentos merecem posterior aprofundamento. Dentre os quais, destaca-se a análise das consequências desse movimento dual do STF sobre o federalismo brasileiro, com o intuito de averiguar se a jurisprudência da Corte estaria reforçando as estruturas federalistas, ou as desestruturando. A segunda hipótese já foi objeto de estudo em artigo anterior (ECHEVERRIA e RIBEIRO, 2018), permanecendo a necessidade de novas incursões sobre o tema.

Da mesma forma, após essa expansão da análise da jurisprudência federalista do STF, torna-se interessante contrastar tal comportamento dual com a atuação de outras Supremas Cortes, reanalisando, por exemplo, a hipótese suscitada pelos teóricos da revisão judicial 
do federalismo, no sentido de que a atuação das Supremas Cortes somente reverbera as tendências previstas na estrutura constitucional de cada país, de modo que o Judiciário reforçaria o movimento centrípeto de federalismos já centralizados e valorizaria a autonomia dos Estados em sistemas mais descentralizados (ARONEY e KINCAID, 2016; POPELIER, 2016).

Tais reflexões preliminares demonstram a necessidade de se promover novos e mais aprofundados estudos sobre o papel do STF enquanto árbitro da Federação, considerando não apenas a anterior hipótese de atuação centralista do STF, e esse novo comportamento descentralizante, como também os demais reflexos sobre a estrutura federalista desse complexo movimento dual da Suprema Corte. ${ }^{44}$

\section{AGRADECIMENTOS}

Este artigo é parte da pesquisa de doutorado da autora. A autora agradece à Advocacia-Geral da União pelo apoio financeiro para a realização do doutorado.

\section{REFERÊNCIAS}

ABRUCIO, Fernando Luiz. Os barões da federação. Lua Nova. São Paulo: Hucitec, n. 33, p. 165-190, 1994.

AMORIM, Daniel Neves. Ações constitucionais. 4. ed. São Paulo: JusPodium, 2018.

ANACLETO, Sidraque David Monteiro. O federalismo brasileiro e a jurisdição constitucional. Monografia (Pós-graduação) - Instituto Brasiliense de Direito Público, IDP, Brasília, 2008.

ANSELMO, José Roberto. O papel do Supremo Tribunal Federal na concretização do federalismo brasileiro. Tese (Doutorado) - Pontifícia Universidade Católica, São Paulo, 2006.

ARAÚJJO, Marcelo Labanca Corrêa de. A construção da federação brasileira pela jurisdição constitucional: um estudo sobre a utilização do princípio da simetria na jurisprudência do Supremo Tribunal Federal. Tese (Doutorado) - Universidade Federal de Pernambuco, Recife, 2008.

44 Exemplificativamente, tem-se os impactos da jurisprudência federalista do STF sobre a crise fiscal dos Estados brasileiros, discutidos em Echeverria e Ribeiro (2018). 
ARLOTA, Carolina; GAROUPA, Nuno. Addressing federal conflicts: an empirical analysis of the Brazilian Supreme Court, 1988-2010. Rev. Law and Economics, v.10, p. 137-160, 2014.

ARLOTA, Carolina. The interplay of judicial review and federalism choices in Brazil after Republican Constitution of 1988. Tese (Doutorado) - University of Illinois at Urbana-Champaign, Urbana, 2015.

ARONEY, Nicholas; KINCAID, John. Introduction. In: ARONEY, Nicholas; KINCAID, John (org.). Courts in federal countries: federalists or unitarists? Toronto: University of Toronto Press, 2016.

BARBOSA, Leon Victor de Queiroz. Guerra fiscal e o ativismo judicial negativo: mapeando o conflito federativo no Supremo Tribunal Federal. Revista Política Hoje, v. 1, n. 23, p. 43-66, 2014.

BEDNAR, Jennifer L.; ESKRIDGE, William; FEREJOHN, John A. A political theory of federalism. In: FEREJOHN, John A.; RAKOVE, Jack; RILEY, Jonathan (ed.). Constitutions and Constitution. Cambridge: Cambridge University Press, 2001.

BEDNAR, Jenna. The robust federation: principles of design. Cambridge: Cambridge University Press, 2009.

BENVINDO, Juliano Zaiden; COSTA, Alexandre Araújo. A quem interessa o controle concentrado de constitucionalidade? O descompasso entre teoria e prática na defesa dos direitos fundamentais (working paper). Brasília: Universidade de Brasília, Brasília, 2016.

BZDERA, André. Analysis of federal high courts: a political theory of judicial review. Canadian Journal of Political Science, v. 26, n. 1, p. 3-29, 1993.

CAMARGO, Nilo Marcelo de Almeida. A forma federativa de estado e o Supremo Tribunal Federal pós-Constituição de 1988. Dissertação (Mestrado) - Pontifícia Universidade Católica do Rio Grande do Sul, Porto Alegre, 2009.

CAMARGO, Fernando Santos de. Judiciário e federalismo: o Supremo Tribunal Federal nos conflitos entre União e Estados. Dissertação (Mestrado) - Universidade Federal do Paraná, Curitiba, 2014.

CANELLO, Júlio. Judicializando a Federação? O Supremo Tribunal Federal e os atos normativos estaduais. Tese (Doutorado) - Universidade do Rio de Janeiro, Rio de Janeiro, 2016.

CONDEIXA, Fábio de Macedo Soares Pires. Controle judicial e Federalismo no Brasil: Supremo Tribunal Federal vs. legislativos estaduais. Dissertação (Mestrado) - Universidade Federal do Rio de Janeiro, Rio de Janeiro, 2007. 
ECHEVERRIA, Andrea de Quadros Dantas; RIBEIRO, Gustavo Ferreira. O Supremo Tribunal Federal como árbitro ou jogador? As crises fiscais dos estados brasileiros e o jogo do resgate. REI - Revista Estudos Institucionais, v. 4, p. 642-671, 2018.

FALCÃO, Joaquim; ABRAMOVAY, Pedro Vieira; LEAL, Fernando Angelo Ribeiro; HARTMANN, Ivar A. II Relatório Supremo em números: o Supremo e a Federação entre 2010 e 2012. Rio de Janeiro: Escola de Direito do Rio de Janeiro da Fundação Getulio Vargas, 2014. (FGV DIREITO RIO - Série Novas ideias em Direito)

GUIMARÃES, Guilherme Avelar. Autonomia política federativa e jurisdição constitucional: a atuação recente do STF como árbitro da Federação à luz do princípio da subsidiariedade. Dissertação (Mestrado) Pontifícia Universidade Católica do Rio de Janeiro, Rio de Janeiro, 2013.

HAMILTON, Alexander; MADISON, James; JAY, John. Federalist: a collection of essays. 1787/1788. Disponível em: http:/ /www.foundingfathers.info/federalistpapers/fedindex.htm. Acesso em: 3 jun. 2020.

HORBACH, Carlos Bastide. Forma de Estado: Federalismo e repartição de competências. Revista Brasileira de Políticas Públicas, v. 3, n. 2, p. 1-12, 2013.

LEONCY, Léo Ferreira. Princípio da simetria e argumento lógico: o uso da analogia na resolução de questões federativas sem solução constitucional evidente. Tese (Doutorado) - Faculdade de Direito de São Paulo da Universidade de São Paulo, São Paulo, 2011.

LEWANDOWSKI, Enrique Ricardo. Pressupostos materiais e formais da intervenção federal no Brasil. 2. ed. São Paulo: Forum, 2018.

LIMA, Kelsiane de Medeiros. Federalismo e desenvolvimento: cooperação entre os entes federados limites, direitos e deveres. Dissertação (Mestrado) - Universidade Federal do Rio Grande do Norte, Natal, 2010.

MAUÉS, Antonio Gomes Moreira. O federalismo brasileiro na jurisprudência do Supremo Tribunal Federal (1988-2003). In: ROCHA, Fernando Luiz Ximenes; MORAES, Filomeno (org.). Direito Constitucional contemporâneo: estudos em homenagem ao Professor Paulo Bonavides. Belo Horizonte: Del Rey, 2005. p. 65-85.

MAZZEI, Marcelo Rodrigues; SILVEIRA, Sebastião Sérgio; PAZETO, Henrique Parisi. Representação interventiva, jurisdição constitucional e conflito federativo. Revista Brasileira de Políticas Públicas, v. 4, n. 1, p. 186-200, 2014. 
MELLO, Cristiana de Santis Mendes de Farias. Federação: é hora de inverter o ônus argumentativo. Revista Brasileira de Direito Público - RBDP, ano 9, n. 33, p. 161-198, 2011.

OLIVEIRA, Vanessa Elias de. Poder Judiciário: árbitro dos conflitos constitucionais entre estados e união. Lua Nova, n.78, p. 223-250, 2009.

PAIXÃO, Leonardo André. A função política do Supremo Tribunal Federal. Tese (Doutorado) - Faculdade de Direito da Universidade de São Paulo, São Paulo, 2007.

PEREIRA, Fábio Franco. A federação no constitucionalismo brasileiro. Dissertação (Mestrado) - Faculdade de Direito da Universidade de São Paulo, São Paulo, 2010.

POPELIER, Patricia. Federalism disputes and the behavior of courts: explaining variation in federal courts' support for centralization. Publius: The Journal of Federalism, v. 47, n. 1, p. 27 e 48, 2016.

RANIERI, Nina Beatriz Stocco. Os estados e o direito à educação na Constituição de 1988. Comentários acerca da jurisprudência do Supremo Tribunal Federal. In: MORAES, Alexandre de (org.). Os 20 anos da constituição da República Federativa do Brasil. São Paulo: Atlas, 2008. p. 183-202.

RIGA, Magno Pimenta. A jurisprudência do Supremo Tribunal Federal em ações referentes ao Federalismo. Monografia (Trabalho de Conclusão de Curso) - Escola de Formação, Sociedade Brasileira de Direito Público, São Paulo, 2007.

SOUZA, Celina. Federalismo e descentralização na Constituição de 1988: processo decisório, conflitos e alianças. DADOS - Revista de Ciências Sociais, Rio de Janeiro, v. 44, n. 3, p. 513-560, 2001.

VASQUES, Denise Cristina. Competências legislativas concorrentes: prática legislativa da União e dos Estados-membros e jurisprudência do Supremo Tribunal Federal. Tese (Doutorado) - Universidade de São Paulo, São Paulo, 2007.

\section{COMO CITAR ESTE ARTIGO:}

DANTAS, Andrea de Quadros. O STF como árbitro da federação: uma análise empírica dos conflitos federativos em sede de ACO. Revista Direito GV, v. 16, n. 2, maio/ago. 2020, e1964. doi: http:// dx.doi.org/10.1590/2317-6172201964.
Andrea de Quadros Dantas

Doutora e Mestre em Direito pelo Centro Universitário de Brasília (Uniceub). Pesquisadora visitante em Stanford UNIVERSITY, CALIFÓRNIA/EUA (2017-2018).

andreaqdantasagmail.com andrea.dantaslaagu.gov.br 